\title{
LEVEL II SCOUR ANALYSIS FOR BRIDGE 81 (NFIETH00PL0081) on PLEASANT STREET, crossing UNION BROOK, NORTHFIELD, VERMONT
}

U.S. Geological Survey Open-File Report 97-404

Prepared in cooperation with

VERMONT AGENCY OF TRANSPORTATION and

FEDERAL HIGHWAY ADMINISTRATION 


\section{LEVEL II SCOUR ANALYSIS FOR BRIDGE 81 (NFIETH00PL0081) on PLEASANT STREET, crossing UNION BROOK, NORTHFIELD, VERMONT \\ By RONDA L. BURNS and LAURA MEDALIE}

U.S. Geological Survey Open-File Report 97-404

Prepared in cooperation with

VERMONT AGENCY OF TRANSPORTATION and

FEDERAL HIGHWAY ADMINISTRATION 


\title{
U.S. DEPARTMENT OF THE INTERIOR BRUCE BABBITT, Secretary
}

\author{
U.S. GEOLOGICAL SURVEY \\ Gordon P. Eaton, Director
}

For additional information write to:

District Chief

U.S. Geological Survey 361 Commerce Way

Pembroke, NH 03275-3718
Copies of this report may be purchased from:

U.S. Geological Survey

Branch of Information Services

Open-File Reports Unit

Box 25286

Denver, CO 80225-0286 


\section{CONTENTS}

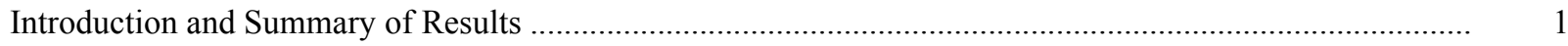

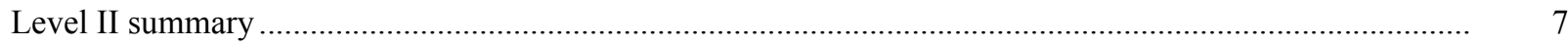

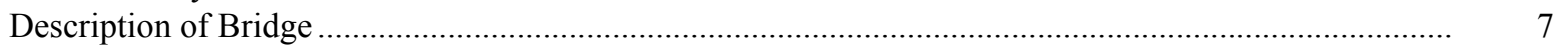

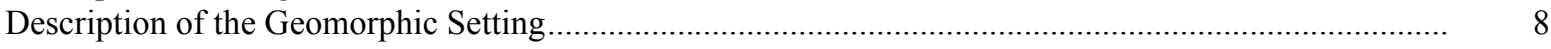

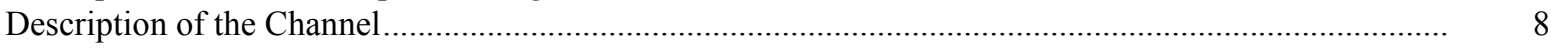

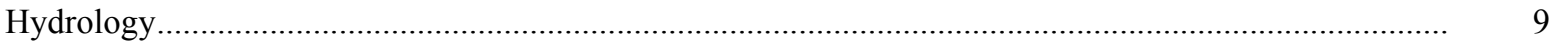

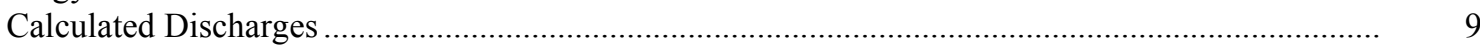

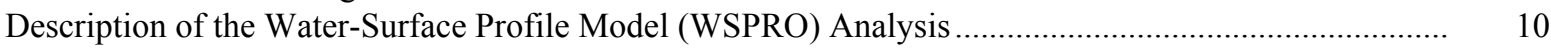

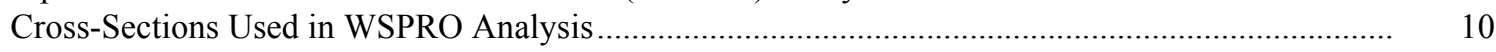

Data and Assumptions Used in WSPRO Model ...................................................................... 11

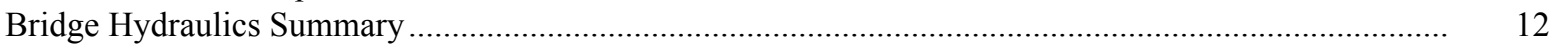

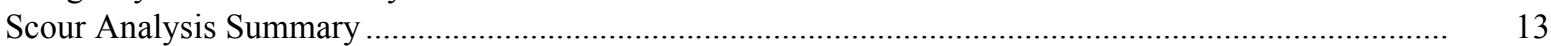

Special Conditions or Assumptions Made in Scour Analysis ...................................................... 13

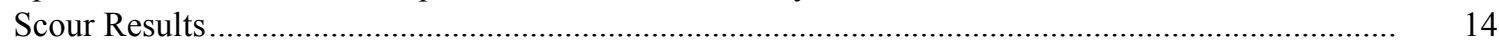

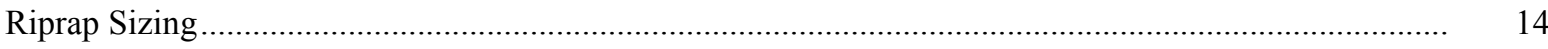

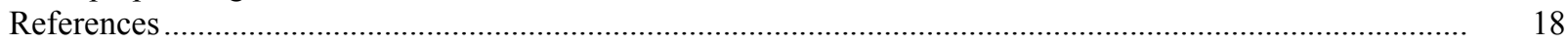

Appendixes:

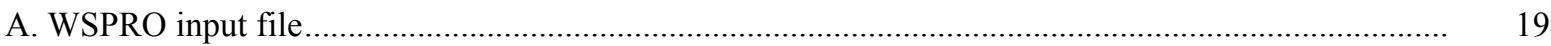

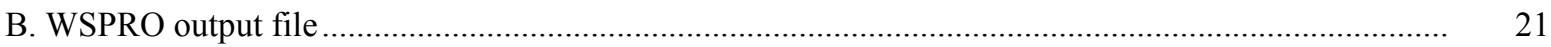

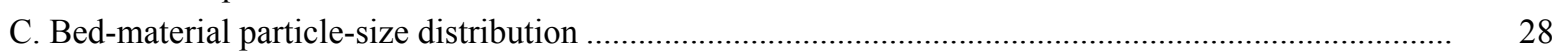

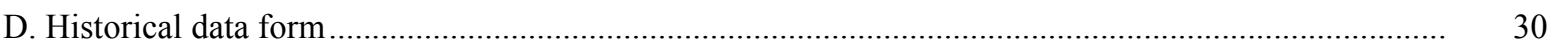

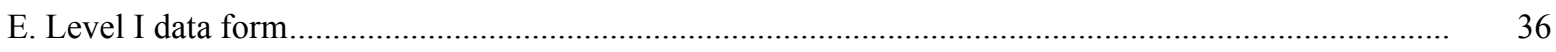

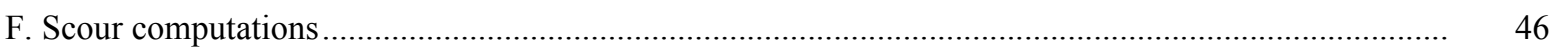

\section{FIGURES}

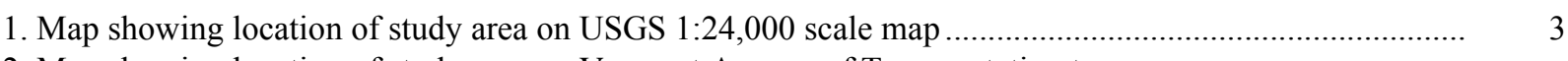

2. Map showing location of study area on Vermont Agency of Transportation town
highway map

3. Structure NFIETH00PL0081 viewed from upstream (July 24, 1996) .....................................................

4. Downstream channel viewed from structure NFIETH00PL0081 (July 24, 1996)................................ 5

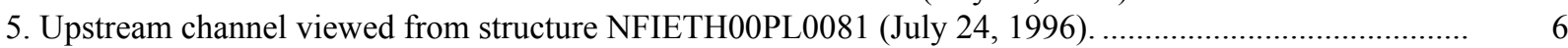

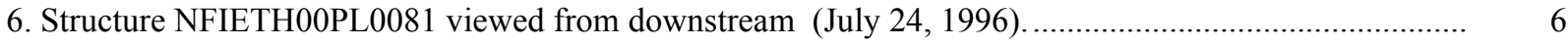

7. Water-surface profiles for the 100- and 500-year discharges at structure

NFIETH00PL0081 on Pleasant Street, crossing Union Brook,

Northfield, Vermont.

8. Scour elevations for the 100- and 500-year discharges at structure

NFIETH00PL0081 on Pleasant Street, crossing Union Brook,

Northfield, Vermont.

\section{TABLES}

1. Remaining footing/pile depth at abutments for the 100-year discharge at structure

NFIETH00PL0081 on Pleasant Street, crossing Union Brook,

Northfield, Vermont.

2. Remaining footing/pile depth at abutments for the 500-year discharge at structure

NFIETH00PL0081 on Pleasant Street, crossing Union Brook,

Northfield, Vermont.

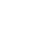

5

6

.
列 


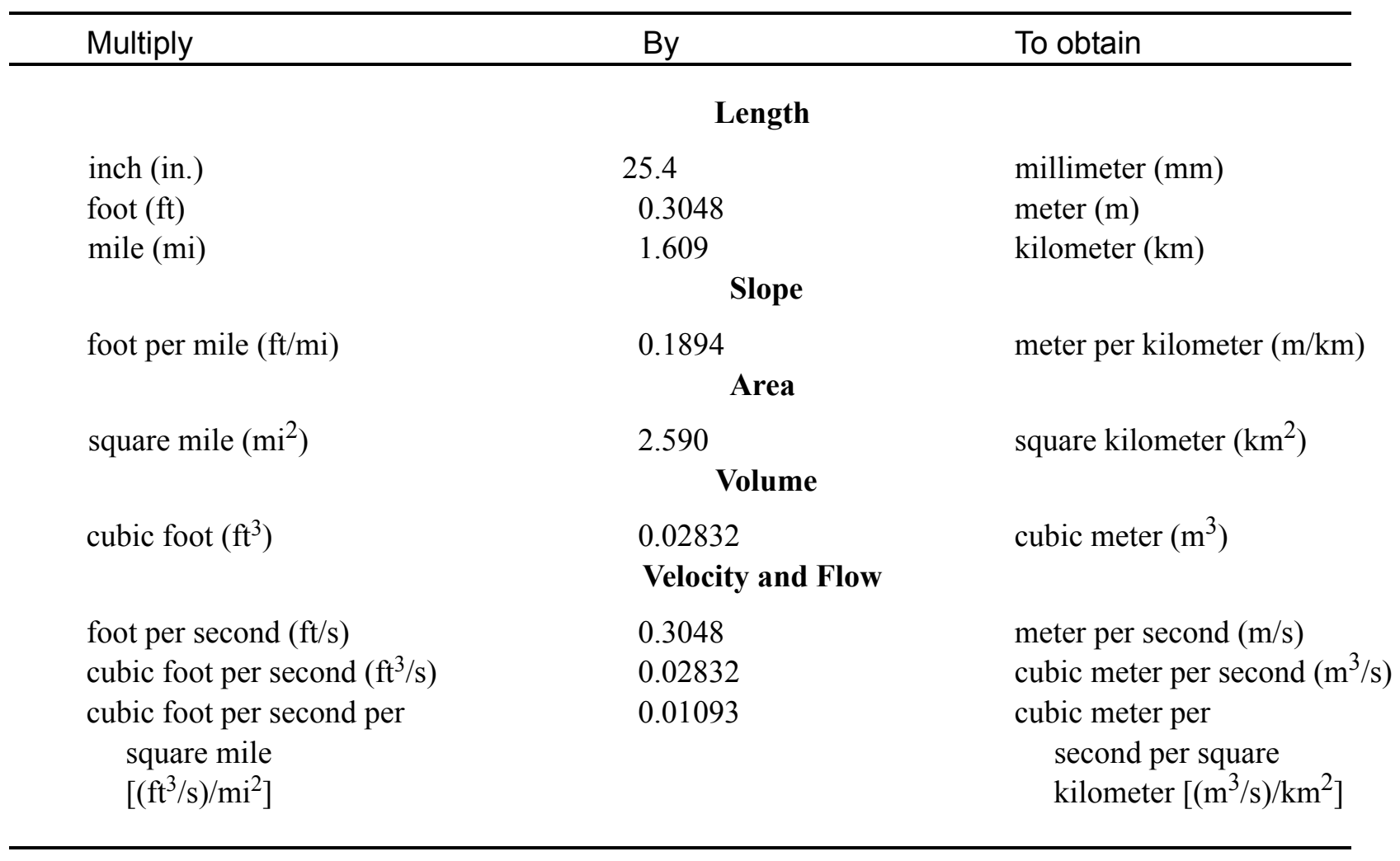

\section{OTHER ABBREVIATIONS}

$\begin{array}{lrlr}\mathrm{BF} & \text { bank full } & \text { LWW } & \text { left wingwall } \\ \mathrm{cfs} & \text { cubic feet per second } & \text { MC } & \text { main channel } \\ \mathrm{D}_{50} & \text { median diameter of bed material } & \text { RAB } & \text { right abutment } \\ \mathrm{DS} & \text { downstream } & \text { RABUT } & \text { face of right abutment } \\ \mathrm{elev} & \text { elevation } & \text { RB } & \text { right bank } \\ \mathrm{f} / \mathrm{p} & \text { flood plain } & \text { ROB } & \text { right overbank } \\ \mathrm{ft}^{2} & \text { square feet } & \text { RWW } & \text { right wingwall } \\ \mathrm{ft} / \mathrm{ft} & \text { feet per foot } & \text { TH } & \text { town highway } \\ \mathrm{JCT} & \text { junction } & \text { UB } & \text { under bridge } \\ \mathrm{LAB} & \text { left abutment } & \text { US } & \text { upstream } \\ \mathrm{LABUT} & \text { face of left abutment } & \text { USGS } & \text { United States Geological Survey } \\ \mathrm{LB} & \text { left bank } & \text { VTAOT Vermont Agency of Transportation } \\ \mathrm{LOB} & \text { left overbank } & \text { WSPRO } & \text { water-surface profile model }\end{array}$

In this report, the words "right" and "left" refer to directions that would be reported by an observer facing downstream. Sea level: In this report, "sea level" refers to the National Geodetic Vertical Datum of 1929-- a geodetic datum derived from a general adjustment of the first-order level nets of the United States and Canada, formerly called Sea Level Datum of 1929.

In the appendices, the above abbreviations may be combined. For example, USLB would represent upstream left bank. 


\title{
LEVEL II SCOUR ANALYSIS FOR BRIDGE 81 (NFIETH00PL0081) ON PLEASANT STREET, CROSSING UNION BROOK, NORTHFIELD, VERMONT
}

\author{
By Ronda L. Burns and Laura Medalie
}

\section{INTRODUCTION AND SUMMARY OF RESULTS}

This report provides the results of a detailed Level II analysis of scour potential at structure NFIETH00PL0081 on Pleasant Street crossing Union Brook, Northfield, Vermont (figures 1-8). A Level II study is a basic engineering analysis of the site, including a quantitative analysis of stream stability and scour (U.S. Department of Transportation, 1993). Results of a Level I scour investigation also are included in Appendix E of this report. A Level I investigation provides a qualitative geomorphic characterization of the study site. Information on the bridge, gleaned from Vermont Agency of Transportation (VTAOT) files, was compiled prior to conducting Level I and Level II analyses and is found in Appendix D.

The site is in the Green Mountain section of the New England physiographic province in central Vermont. The $6.1-\mathrm{mi}^{2}$ drainage area is in a predominantly rural and forested basin. The bridge site is located within a suburban setting in the Town of Northfield with homes, lawns, and pavement on the overbanks. There are trees and brush along the immediate banks.

In the study area, Union Brook has an incised, straight channel with a slope of approximately $0.01 \mathrm{ft} / \mathrm{ft}$, an average channel top width of $41 \mathrm{ft}$ and an average bank height of $4 \mathrm{ft}$. The channel bed material ranges from gravel to boulders with a median grain size $\left(\mathrm{D}_{50}\right)$ of $47.7 \mathrm{~mm}(0.157 \mathrm{ft})$. The geomorphic assessment at the time of the Level I and Level II site visit on July 24, 1996, indicated that the reach was stable.

The Pleasant Street crossing of Union Brook is a 34-ft-long, two-lane bridge consisting of one 29-foot steel-beam span (Vermont Agency of Transportation, written communication, October 13, 1995). The opening length of the structure parallel to the bridge face is $26.6 \mathrm{ft}$. The bridge is supported by vertical, concrete abutments with wingwalls. The channel is skewed approximately 25 degrees to the opening while the opening-skew-to-roadway is 30 degrees. 
A scour hole $0.5 \mathrm{ft}$ deeper than the mean thalweg depth was observed along the upstream left wingwall and upstream end of the left abutment during the Level I assessment. The scour protection measures at the site were type-1 stone fill (less than 12 inches diameter) along the upstream left bank, the upstream left wingwall, and the downstream left bank, and type- 2 stone fill (less than 36 inches diameter) along the downstream right bank. There is also a laid-up stone wall in front of the downstream left wingwall. Additional details describing conditions at the site are included in the Level II Summary and Appendices D and $\mathrm{E}$.

Scour depths and recommended rock rip-rap sizes were computed using the general guidelines described in Hydraulic Engineering Circular 18 (Richardson and others, 1995). Total scour at a highway crossing is comprised of three components: 1) long-term streambed degradation; 2) contraction scour (due to accelerated flow caused by a reduction in flow area at a bridge) and; 3 ) local scour (caused by accelerated flow around piers and abutments). Total scour is the sum of the three components. Equations are available to compute depths for contraction and local scour and a summary of the results of these computations follows.

Contraction scour for all modelled flows ranged from 0.0 to $0.5 \mathrm{ft}$. The worst-case contraction scour occurred at the 500-year discharge. Abutment scour ranged from 4.2 to $13.3 \mathrm{ft}$. The worst-case abutment scour occurred at the 500-year discharge. Additional information on scour depths and depths to armoring are included in the section titled "Scour Results". Scoured-streambed elevations, based on the calculated scour depths, are presented in tables 1 and 2. A cross-section of the scour computed at the bridge is presented in figure 8. Scour depths were calculated assuming an infinite depth of erosive material and a homogeneous particle-size distribution.

It is generally accepted that the Froehlich equation (abutment scour) gives "excessively conservative estimates of scour depths" (Richardson and others, 1995, p. 47). Usually, computed scour depths are evaluated in combination with other information including (but not limited to) historical performance during flood events, the geomorphic stability assessment, existing scour protection measures, and the results of the hydraulic analyses. Therefore, scour depths adopted by VTAOT may differ from the computed values documented herein. 


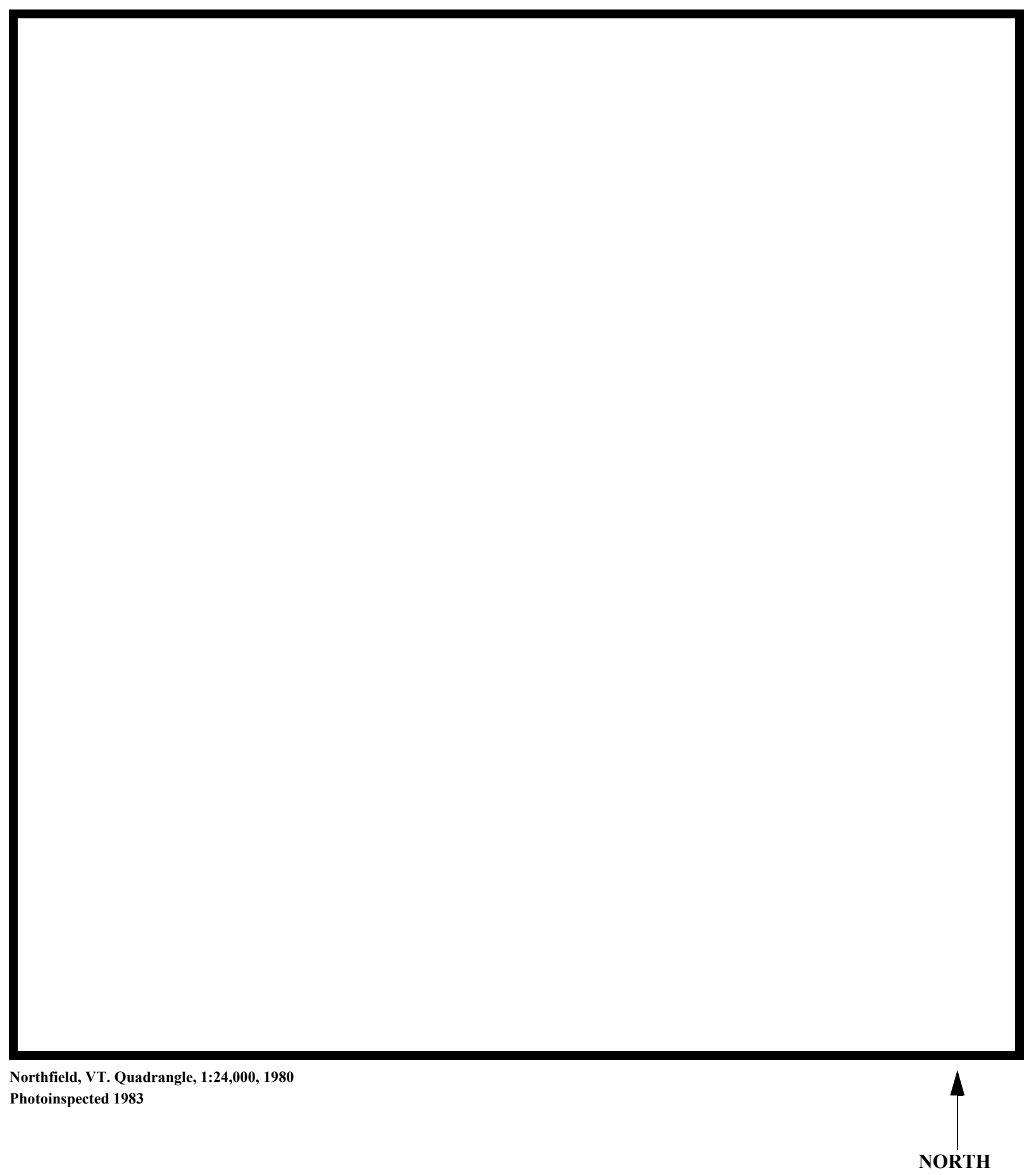

Figure 1. Location of study area on USGS 1:24,000 scale map. 
Figure 2. Location of study area on Vermont Agency of Transportation town highway map. 

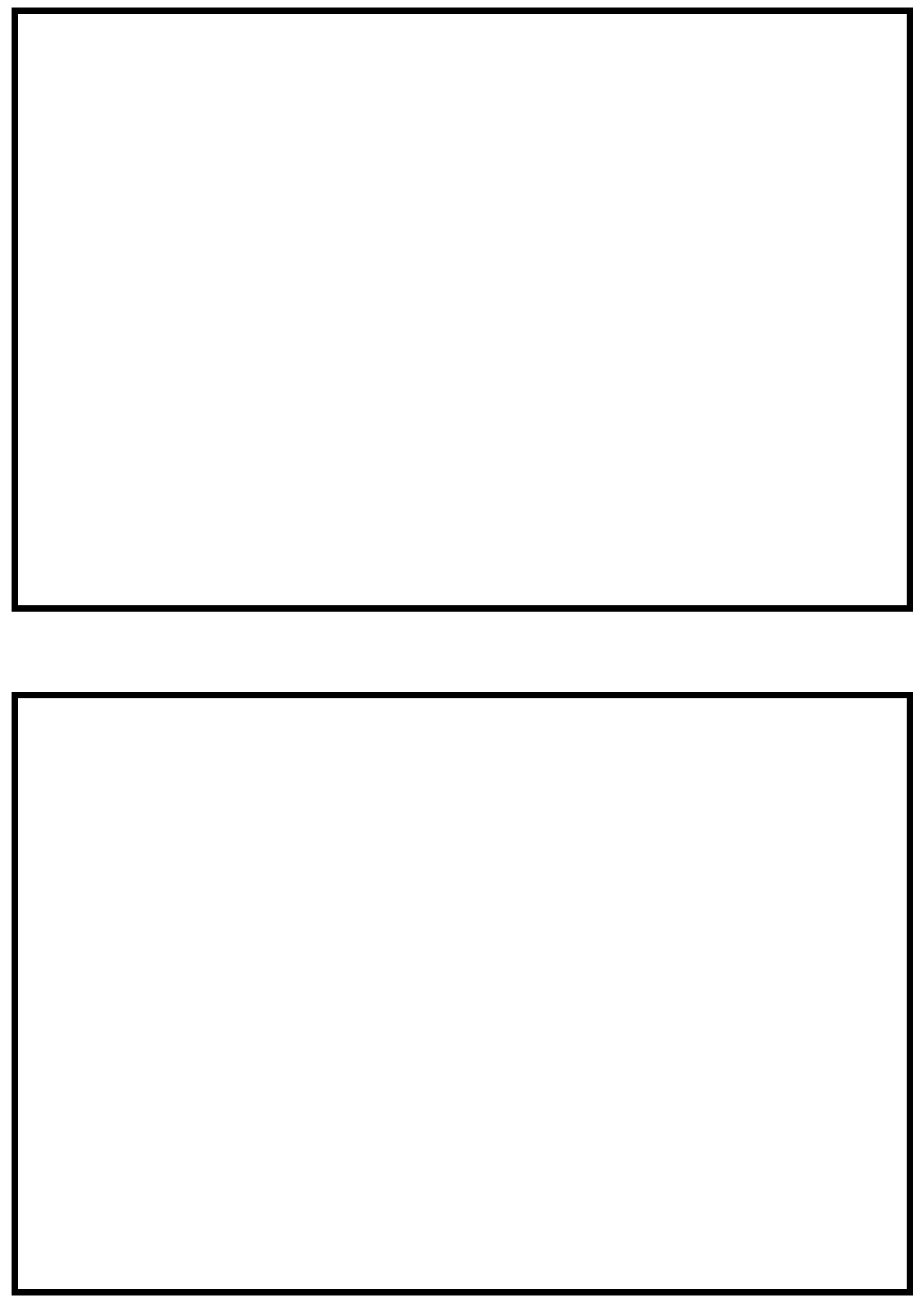

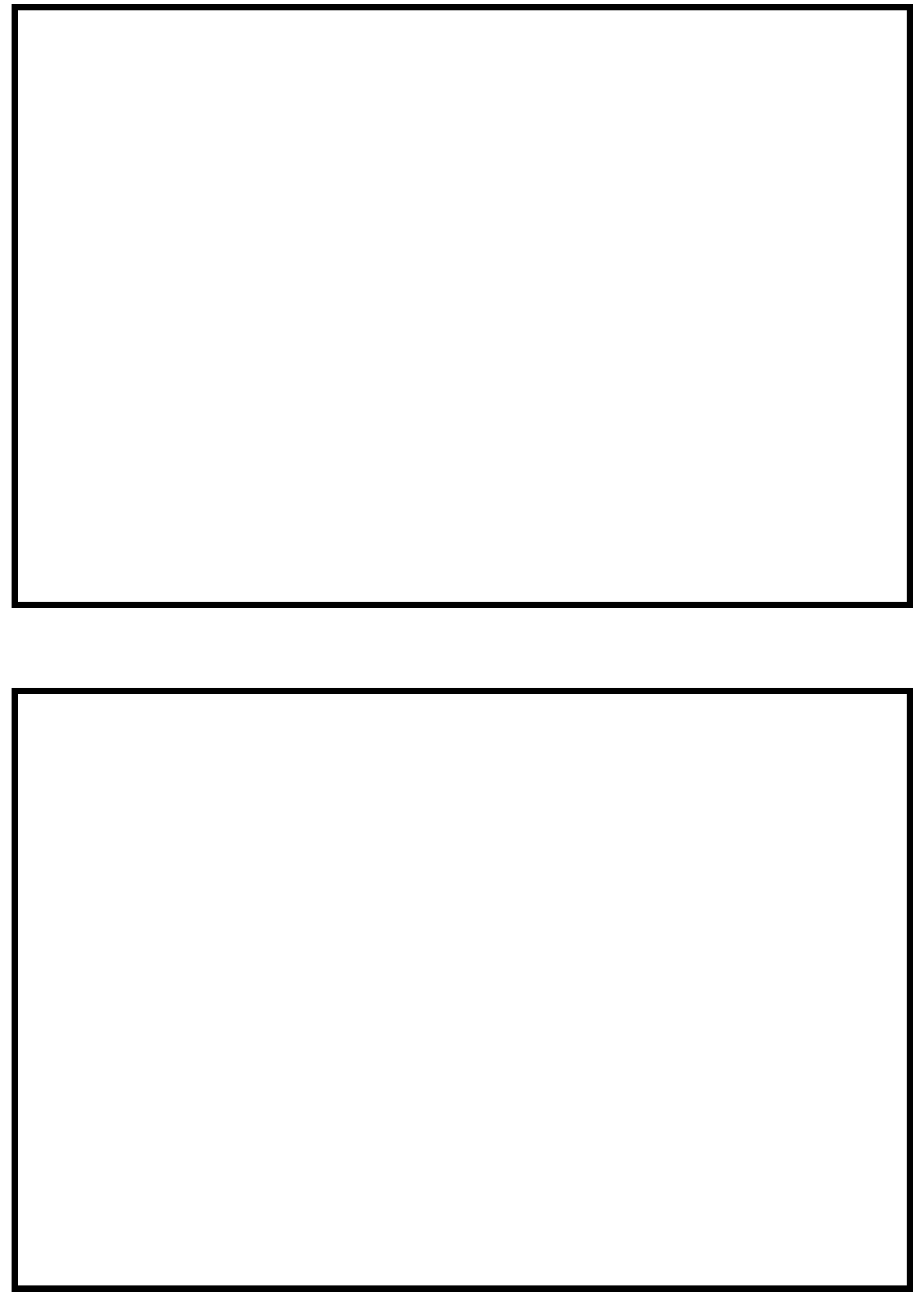


\section{LEVEL II SUMMARY}

\begin{tabular}{llllll} 
Structure Number & NFIETH00PL0081 & Stream & \multicolumn{2}{c}{ Union Brook } & \\
& Washington & Road & Pleasant Street & District & 6
\end{tabular}

\section{Description of Bridge}

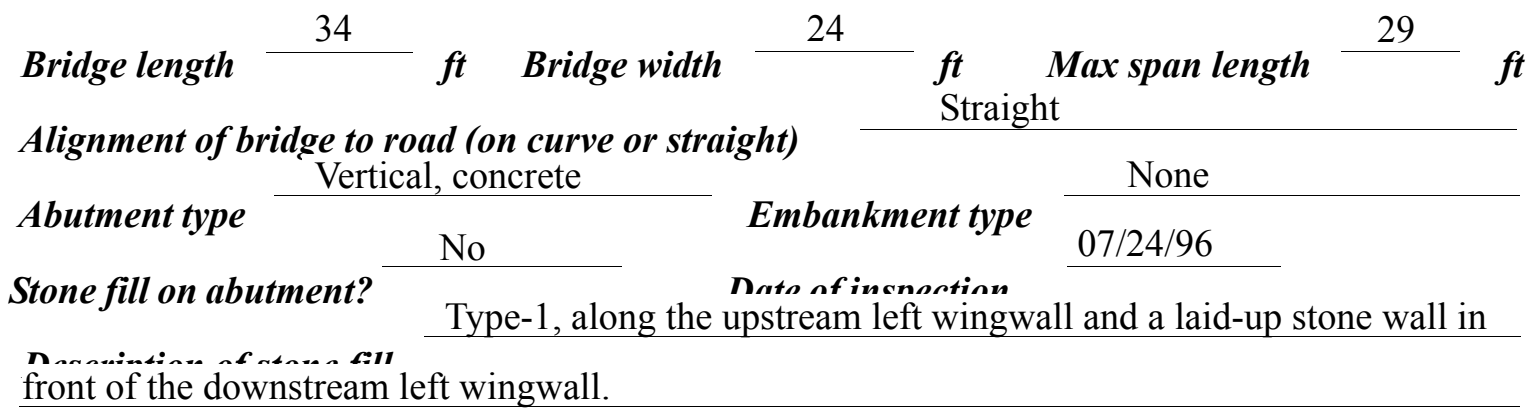

Abutments and wingwalls are concrete. There is a 0.5

foot deep scour hole in front of the upstream left wingwall and at the upstream end of the left abutment.

Yes

Is bridge skewed to flood flow according to Yes ' survey? Angle

The upstream reach makes a gradual bend into the bridge. The left bank is eroded where the stream flow impacts the bank.

Debris accumulation on bridge at time of Level I or Level II site visit:

\begin{tabular}{|c|c|c|c|}
\hline & $\begin{array}{c}\text { Date of insnortion } \\
07 / 24 / 96 \\
\end{array}$ & $\begin{array}{l}\text { Percent of almminl } \\
\text { bloeked inortzontatly }\end{array}$ & $\begin{array}{l}\text { Percent of } 0 \\
\text { blocked verticatty }\end{array}$ \\
\hline Level I & $07 / 24 / 96$ & 0 & 0 \\
\hline $\begin{array}{l}\text { Level II } \\
\text { upstream. }\end{array}$ & Moderate. & re is significant vegetat & er on the banks \\
\hline
\end{tabular}

None. 07/24/96

Dosrriho any, foaturos noar ar at tho hridoo that mav, affort flou, (includo ahsorvation dato) 


\section{Description of the Geomorphic Setting}

General topography The channel is located within a moderate relief valley setting.

Geomorphic conditions at bridge site: downstream (DS), upstream (US)

Date of inspection $\quad 07 / 24 / 96$

DS left: $\quad$ Narrow flood plain.

DS right: $\quad$ Steep channel bank to a narrow overbank.

US left: $\quad$ Narrow flood plain.

US right: $\quad$ Steep channel bank to a moderately sloped overbank.

\section{Description of the Channel}

\begin{tabular}{|c|c|c|c|}
\hline \multirow[b]{2}{*}{ Average top width } & 41 & \multirow[b]{2}{*}{ Average depth } & \multirow[b]{2}{*}{ Gravel/Sand ${ }^{\boldsymbol{f}}$} \\
\hline & $\stackrel{\boldsymbol{f t}^{\boldsymbol{t}}}{\text { Gravel/Cobbles }}$ & & \\
\hline Predominant bed & & Bank material & Straight with ser \\
\hline
\end{tabular}

alluvial channel boundaries and a narrow flood plain on the left.

$07 / 24 / 96$

Vegetative ${ }^{c}{ }^{1}$ Trees and brush with short grass on the flood plain.

DS left: $\quad$ Trees and brush with short grass on the overbank.

DS right: $\quad$ Trees and brush with short grass and pavement on the flood plain.

US left: $\quad$ Trees and brush with short grass and pavement on the overbank.

US right: $\quad$ Yes

Do banks appear stable? -

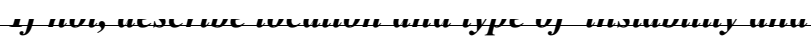

date of observatton.

None. 07/24/96

Describe any obstructions in channel and date of observation. 


\section{Hydrology}

Drainage area $\quad 6.1 \quad m i^{2}$

Percentage of drainage area in physiographic provinces: (approximate)

Physiographic province/section

New England/Green Mountain
Percent of drainage area 100

Is drainage area considered rural or urban? Rural Describe any significant urbanization: The drainage area is rural, but the bridge is located in a suburban setting.

No

Is there a USGS gage on the stream of interest?

USGS gage description

USGS gage number

Gage drainage area $\quad \mathrm{mi}^{2}$

Is there a lake/p

(n)

Is there a take/p

(n)

m.

1,590

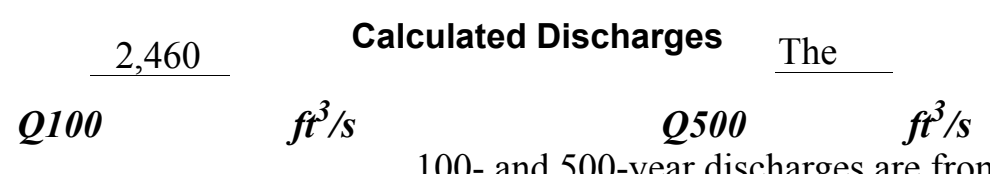

100- and 500-year discharges are from the Flood

Insurance Study of the Village of Northfield (U.S. Department of Housing and Urban

Development, 1977). 


\section{Description of the Water-Surface Profile Model (WSPRO) Analysis}

Datum for WSPRO analysis (USGS survey, sea level, VTAOT plans)

USGS survey

Datum tie between USGS survey and VTAOT plans

None

Description of reference marks used to determine USGS datum. $\quad$ RM1 is a chiseled X on

top of the downstream end of the right abutment (elev. $501.61 \mathrm{ft}$, arbitrary survey datum). RM2

is a nail in a pole at the intersection of Pleasant and Union Streets (elev. $501.34 \mathrm{ft}$, arbitrary

survey datum). RM3 is the high point of a fire hydrant on the corner of Cotter and Pleasant

(elev. $501.64 \mathrm{ft}$, arbitrary survey datum).

\section{Cross-Sections Used in WSPRO Analysis}

\begin{tabular}{cccl}
\hline${ }^{1}$ Cross-section & $\begin{array}{c}\text { Section } \\
\text { Reference } \\
\text { Distance } \\
\text { (SRD) } \text { in feet }\end{array}$ & $\begin{array}{c}{ }^{2} \text { Cross-section } \\
\text { development }\end{array}$ & \multicolumn{1}{c}{ Comments } \\
\hline EXITX & -32 & 1 & $\begin{array}{l}\text { Exit section } \\
\text { Downstream Full-valley } \\
\text { section (Templated from } \\
\text { EXITX) }\end{array}$ \\
BRIDG & 0 & 2 & $\begin{array}{l}\text { Bridge section } \\
\text { Road Grade section }\end{array}$ \\
RDWAY & 0 & 1 & $\begin{array}{l}\text { Modelled Approach sec- } \\
\text { tion (Templated from } \\
\text { APPRO }\end{array}$ \\
& 16 & 1 & $\begin{array}{l}\text { APTEM) } \\
\text { Approach section as sur- } \\
\text { veyed (Used as a tem- } \\
\text { plate) }\end{array}$ \\
\hline
\end{tabular}

${ }^{1}$ For location of cross-sections see plan-view sketch included with Level I field form, Appendix E.

For more detail on how cross-sections were developed see WSPRO input file. 


\section{Data and Assumptions Used in WSPRO Model}

Hydraulic analyses of the reach were done by use of the Federal Highway Administration's WSPRO step-backwater computer program (Shearman and others, 1986, and Shearman, 1990). The analyses reported herein reflect conditions existing at the site at the time of the study. Furthermore, in the development of the model it was necessary to assume no accumulation of debris or ice at the site. Results of the hydraulic model are presented in the Bridge Hydraulic Summary, Appendix B, and figure 7.

Channel roughness factors (Manning's " $n$ ") used in the hydraulic model were estimated using field inspections at each cross section following the general guidelines described by Arcement and Schneider (1989). Final adjustments to the values were made during the modelling of the reach. Channel " $\mathrm{n}$ " values for the reach ranged from 0.040 to 0.060 , and overbank " $\mathrm{n}$ " values ranged from 0.035 to 0.055 .

Normal depth at the exit section (EXITX) was assumed as the starting water surface. This depth was computed by use of the slope-conveyance method outlined in the user's manual for WSPRO (Shearman, 1990). The slope used was $0.0104 \mathrm{ft} / \mathrm{ft}$ which was estimated from the streambed slope downstream of the bridge in the Flood Insurance Study for Northfield, VT (U. S. Department of Housing and Urban Development, November 1977).

Using normal depth as the starting water-surface assumes that the effects of backwater from the Dog River, $780 \mathrm{ft}$ downstream, are negligible. Due to the difference in drainage areas at the confluence, the extent of backwater from the Dog River during flooding on Union Brook is unknown. Using normal depth as the starting water-surface also assumes the effects of backwater from a bridge $700 \mathrm{ft}$ downstream are insignificant.

The surveyed approach section (APTEM) was moved along the approach channel slope $(0.014 \mathrm{ft} / \mathrm{ft})$ to establish the modelled approach section (APPRO), one bridge length upstream of the upstream face as recommended by Shearman and others (1986). This location also provides a consistent method for determining scour variables. 


\section{Bridge Hydraulics Summary}

$\begin{array}{llll}\text { Average bridge embankment elevation } & 501.4 \\ \text { Average low steel elevation } & 500.1 & \boldsymbol{f t}\end{array}$

100-year discharge $\quad 1,590 \quad \mathrm{ft}^{3} / \mathrm{s}$

Water-surface elevation in bridge opening $\quad 500.1 \quad f t$

Road overtopping? ___ Yes Discharge over road___ $545 \quad \mathrm{ft}^{3} / \mathrm{s}$

\begin{tabular}{llll} 
Area of flow in bridge opening & $144 \quad \mathrm{ft}^{2}$ \\
\cline { 2 - 3 } Average velocity in bridge opening & 7.3 & $\mathrm{ft} / \mathrm{s}$
\end{tabular}

Maximum WSPRO tube velocity at bridge $\quad 10.1 \mathrm{ft} / \mathrm{s}$

Water-surface elevation at Approach section with bridge 501.3

Water-surface elevation at Approach section without bridge $\quad 500.9$

Amount of backwater caused by bridge

0.4 it

500-year discharge $\quad 2,460 \quad \mathrm{ft}^{3} / \mathrm{s}$

Water-surface elevation in bridge opening $\quad 500.1 \mathrm{ft}$

Road overtopping? ___ Yes Discharge over road __ $1,247, \mathrm{it}^{3} / \mathrm{s}$

Area of flow in bridge opening $\quad 144 \quad \mathrm{ft}^{2}$

Average velocity in bridge opening $8.4 \mathrm{ft} / \mathrm{s}$

Maximum WSPRO tube velocity at bridge 9.7 , s

Water-surface elevation at Approach section with bridge 502.1

Water-surface elevation at Approach section without bridge $\quad 501.5$

Amount of backwater caused by bridge $\quad 0.6$, $t$

Incipient overtopping discharge $\quad 930 \quad \mathrm{ft}^{3} / \mathrm{s}$

Water-surface elevation in bridge opening $498.1 \quad t$

Area of flow in bridge opening

Average velocity in bridge opening

$98 \quad \mathrm{ft}^{2}$

Maximum WSPRO tube velocity at bridge

$9.5 \mathrm{ft} / \mathrm{s}$

$11.3 \mathrm{ft} / \mathrm{s}$

Water-surface elevation at Approach section with bridge

Water-surface elevation at Approach section without bridge

499.7

Amount of backwater caused by bridge

0.1 , $t$

499.6 


\section{Scour Analysis Summary}

\section{Special Conditions or Assumptions Made in Scour Analysis}

Scour depths were computed using the general guidelines described in Hydraulic Engineering Circular 18 (Richardson and others, 1995). Scour depths were calculated assuming an infinite depth of erosive material and a homogeneous particle-size distribution. The results of the scour analysis are presented in tables 1 and 2 and a graph of the scour depths is presented in figure 8 .

Contraction scour for the incipient discharge was computed by use of the clear-water contraction scour equation (Richardson and others, 1995, p. 32, equation 20). At this site, the 100-year discharge resulted in unsubmerged orifice flow and the 500-year discharge resulted in submerged orifice flow. Contraction scour at bridges with orifice flow is best estimated by use of the Chang pressure-flow scour equation (oral communication, J. Sterling Jones, October 4, 1996). Thus, contraction scour for these discharges was computed by use of the Chang equation (Richardson and others, 1995, p. 145-146). Results of this analysis are presented in figure 8 and tables 1 and 2. The streambed armoring depths computed suggest that armoring will not limit the depth of contraction scour.

For comparison, contraction scour for the discharges resulting in orifice flow was also computed by use of the Laursen clear-water contraction scour equation and the Umbrell pressure-flow equation (Richardson and others, 1995, p. 144) and presented in Appendix F. Furthermore, for the discharge resulting in unsubmerged orifice flow, contraction scour was computed by substituting estimates for the depth of flow at the downstream bridge face in the contraction scour equations. Results with respect to these substitutions are provided in Appendix F.

Abutment scour was computed by use of the Froehlich equation (Richardson and others, 1995, p. 48, equation 28). Variables for the Froehlich equation include the Froude number of the flow approaching the embankments, the length of the embankment blocking flow, and the depth of flow approaching the embankment less any roadway overtopping. 


\section{Scour Results}

\section{0-yr discharge 500-yr discharge}

Contraction scour:

(Scour depths in feet)

Main channel

Live-bed scour

Clear-water scour

Depth to armoring

Left overbank

Right overbank

Local scour:

Abutment scour

Left abutment

7.4

7.5

4.2

$12.7-$

$13.3-$

$11.3-$

Right abutment

Pier scour

Pier 1

Pier 2

Pier 3

\section{Abutments:}

Left abutment

Right abutment

Piers:

Pier 1

Pier 2

overtopping discharge 


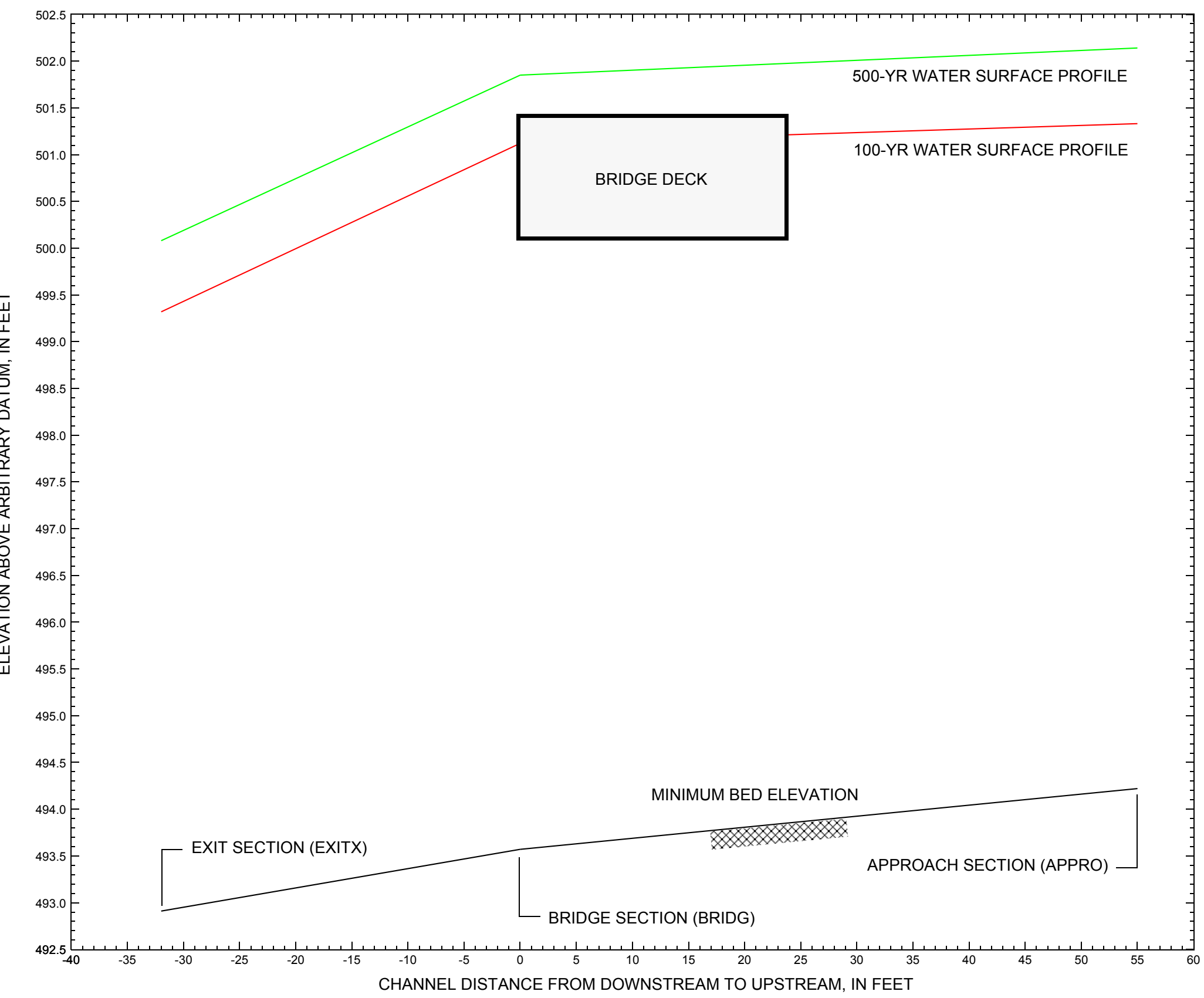

Figure 7. Water-surface profiles for the 100- and 500-yr discharges at structure NFIETH00PL0081 on Pleasant Street, crossing Union Brook, Northfield, Vermont. 


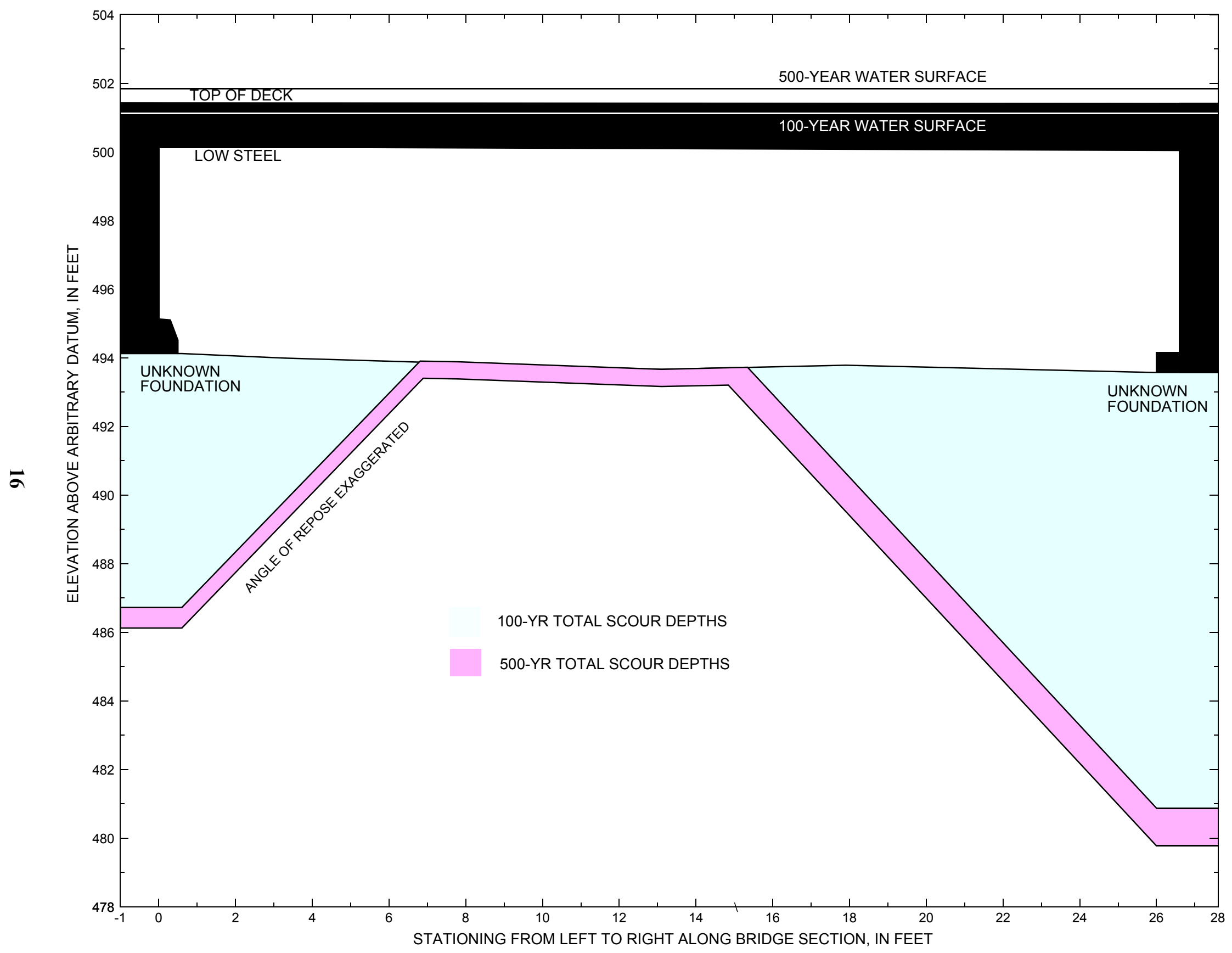

Figure 8. Scour elevations for the 100-yr and 500-yr discharges at structure NFIETH00PL0081 on Pleasant Street, crossing Union Brook, Northfield, Vermont. 


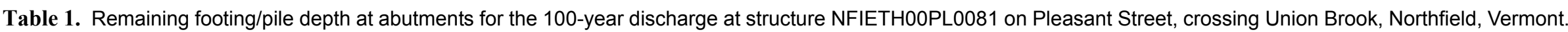
[VTAOT, Vermont Agency of Transportation; --, no data]

\begin{tabular}{|c|c|c|c|c|c|c|c|c|c|c|c|}
\hline Description & Station $^{1}$ & $\begin{array}{l}\text { VTAOT } \\
\text { minimum } \\
\text { low-chord } \\
\text { elevation } \\
\text { (feet) }\end{array}$ & $\begin{array}{c}\text { Surveyed } \\
\text { minimum } \\
\text { low-chord } \\
\text { elevation } \\
\text { (feet) }\end{array}$ & $\begin{array}{c}\text { Bottom of } \\
\text { footing } \\
\text { elevation } \\
\text { (feet) }\end{array}$ & $\begin{array}{l}\text { Channel } \\
\text { elevation at } \\
\text { abutment/ } \\
\text { pier }^{2} \\
\text { (feet) }\end{array}$ & $\begin{array}{l}\text { Contraction } \\
\text { scour depth } \\
\text { (feet) }\end{array}$ & $\begin{array}{l}\text { Abutment } \\
\text { scour } \\
\text { depth } \\
\text { (feet) }\end{array}$ & $\begin{array}{l}\text { Pier } \\
\text { scour } \\
\text { depth } \\
\text { (feet) }\end{array}$ & $\begin{array}{l}\text { Depth of } \\
\text { total scour } \\
\text { (feet) }\end{array}$ & $\begin{array}{c}\text { Elevation of } \\
\text { scour }^{2} \\
\text { (feet) }\end{array}$ & $\begin{array}{c}\text { Remaining } \\
\text { footing/pile } \\
\text { depth } \\
\text { (feet) }\end{array}$ \\
\hline \multicolumn{12}{|c|}{100 -yr. discharge is 1,590 cubic-feet per second } \\
\hline Left abutment & 0.0 & -- & 500.1 & -- & 494.1 & 0.0 & 7.4 & -- & 7.4 & 486.7 & -- \\
\hline Right abutment & 26.6 & -- & 500.0 & -- & 493.6 & 0.0 & 12.7 & -- & 12.7 & 480.9 & -- \\
\hline
\end{tabular}

1.Measured along the face of the most constricting side of the bridge.

2.Arbitrary datum for this study.

Table 2. Remaining footing/pile depth at abutments for the 500-year discharge at structure NFIETH00PL0081 on Pleasant Street, crossing Union Brook, Northfield, Vermont. [VTAOT, Vermont Agency of Transportation; --, no data]

\begin{tabular}{|c|c|c|c|c|c|c|c|c|c|c|c|}
\hline Description & Station $^{1}$ & $\begin{array}{l}\text { VTAOT } \\
\text { minimum } \\
\text { low-chord } \\
\text { elevation } \\
\text { (feet) }\end{array}$ & $\begin{array}{l}\text { Surveyed } \\
\text { minimum } \\
\text { low-chord } \\
\text { elevation } \\
\text { (feet) }\end{array}$ & $\begin{array}{c}\text { Bottom of } \\
\text { footing } \\
\text { elevation } \\
\text { (feet) }\end{array}$ & $\begin{array}{c}\text { Channel } \\
\text { elevation at } \\
\text { abutment/ } \\
\text { pier }^{2} \\
\text { (feet) }\end{array}$ & $\begin{array}{l}\text { Contraction } \\
\text { scour depth } \\
\text { (feet) }\end{array}$ & $\begin{array}{l}\text { Abutment } \\
\text { scour } \\
\text { depth } \\
\text { (feet) }\end{array}$ & $\begin{array}{l}\text { Pier } \\
\text { scour } \\
\text { depth } \\
\text { (feet) }\end{array}$ & $\begin{array}{l}\text { Depth of } \\
\text { total scour } \\
\text { (feet) }\end{array}$ & $\begin{array}{c}\text { Elevation of } \\
\text { scour }^{2} \\
\text { (feet) }\end{array}$ & $\begin{array}{c}\text { Remaining } \\
\text { footing/pile } \\
\text { depth } \\
\text { (feet) }\end{array}$ \\
\hline \multicolumn{12}{|c|}{500 -yr. discharge is 2,460 cubic-feet per second } \\
\hline Left abutment & 0.0 & -- & 500.1 & -- & 494.1 & 0.5 & 7.5 & -- & 8.0 & 486.1 & -- \\
\hline Right abutment & 26.6 & -- & 500.0 & -- & 493.6 & 0.5 & 13.3 & -- & 13.8 & 479.8 & -- \\
\hline
\end{tabular}

1.Measured along the face of the most constricting side of the bridge.

2.Arbitrary datum for this study. 


\section{SELECTED REFERENCES}

Arcement, G.J., Jr., and Schneider, V.R., 1989, Guide for selecting Manning's roughness coefficients for natural channels and flood plains: U.S. Geological Survey Water-Supply Paper 2339, 38 p.

Barnes, H.H., Jr., 1967, Roughness characteristics of natural channels: U.S. Geological Survey Water-Supply Paper 1849,213 p.

Benson, M. A., 1962, Factors Influencing the Occurrence of Floods in a Humid Region of Diverse Terrain: U.S. Geological Survey WaterSupply Paper 1580-B, 64 p.

Brown, S.A. and Clyde, E.S., 1989, Design of riprap revetment: Federal Highway Administration Hydraulic Engineering Circular No. 11, Publication FHWA-IP-89-016, 156 p.

Federal Highway Administration, 1983, Runoff estimates for small watersheds and development of sound design: Federal Highway Administration Report FHWA-RD-77-158.

Federal Highway Administration, 1993, Stream Stability and Scour at Highway Bridges: Participant Workbook: Federal Highway Administration Report FHWA-HI-91-011.

Froehlich, D.C., 1989, Local scour at bridge abutments in Ports, M.A., ed., Hydraulic Engineering--Proceedings of the 1989 National Conference on Hydraulic Engineering: New York, American Society of Civil Engineers, p. 13-18.

Hayes, D.C.,1993, Site selection and collection of bridge-scour data in Delaware, Maryland, and Virginia: U.S. Geological Survey WaterResources Investigation Report 93-4017, 23 p.

Interagency Advisory Committee on Water Data, 1982, Guidelines for determining flood flow frequency: U.S. Geological Survey, Bulletin 17B of the Hydrology Subcommittee, 190 p.

Johnson, C.G. and Tasker, G.D.,1974, Progress report on flood magnitude and frequency of Vermont streams: U.S. Geological Survey OpenFile Report 74-130, 37 p.

Lagasse, P.F., Schall, J.D., Johnson, F., Richardson, E.V., Chang, F., 1995, Stream Stability at Highway Structures: Federal Highway Administration Hydraulic Engineering Circular No. 20, Publication FHWA-IP-90-014, 144 p.

Laursen, E.M., 1960, Scour at bridge crossings: Journal of the Hydraulics Division, American Society of Civil Engineers, v. 86, no. HY2, p. 39-53.

Potter, W. D., 1957a, Peak rates of runoff in the Adirondack, White Mountains, and Maine woods area, Bureau of Public Roads

Potter, W. D., 1957b, Peak rates of runoff in the New England Hill and Lowland area, Bureau of Public Roads

Richardson, E.V. and Davis, S.R., 1995, Evaluating scour at bridges: Federal Highway Administration Hydraulic Engineering Circular No. 18, Publication FHWA-IP-90-017, 204 p.

Richardson, E.V., Simons, D.B., and Julien, P.Y., 1990, Highways in the river environment: Federal Highway Administration Publication FHWA-HI-90-016.

Ritter, D.F., 1984, Process Geomorphology: W.C. Brown Co., Debuque, Iowa, 603 p.

Shearman, J.O., 1990, User's manual for WSPRO--a computer model for water surface profile computations: Federal Highway Administration Publication FHWA-IP-89-027, 187 p.

Shearman, J.O., Kirby, W.H., Schneider, V.R., and Flippo, H.N., 1986, Bridge waterways analysis model; research report: Federal Highway Administration Publication FHWA-RD-86-108, 112 p.

Talbot, A.N., 1887, The determination of water-way for bridges and culverts.

U.S. Department of Housing and Urban Development, 1977, Flood Insurance Study, Town and Village of Northfield, Washington County, Vermont: Washington, D.C., November 1977.

U.S. Department of Transportation, 1993, Stream stability and scour at highway bridges, Participant Workbook: Federal Highway Administration Publication FHWA HI-91-011.

U.S. Geological Survey, 1980, Northfield, Vermont 7.5 Minute Series quadrangle map: U.S. Geological Survey Topographic Maps, Photoinspected 1983, Scale 1:24,000. 


\section{APPENDIX A: \\ WSPRO INPUT FILE}




\section{WSPRO INPUT FILE}

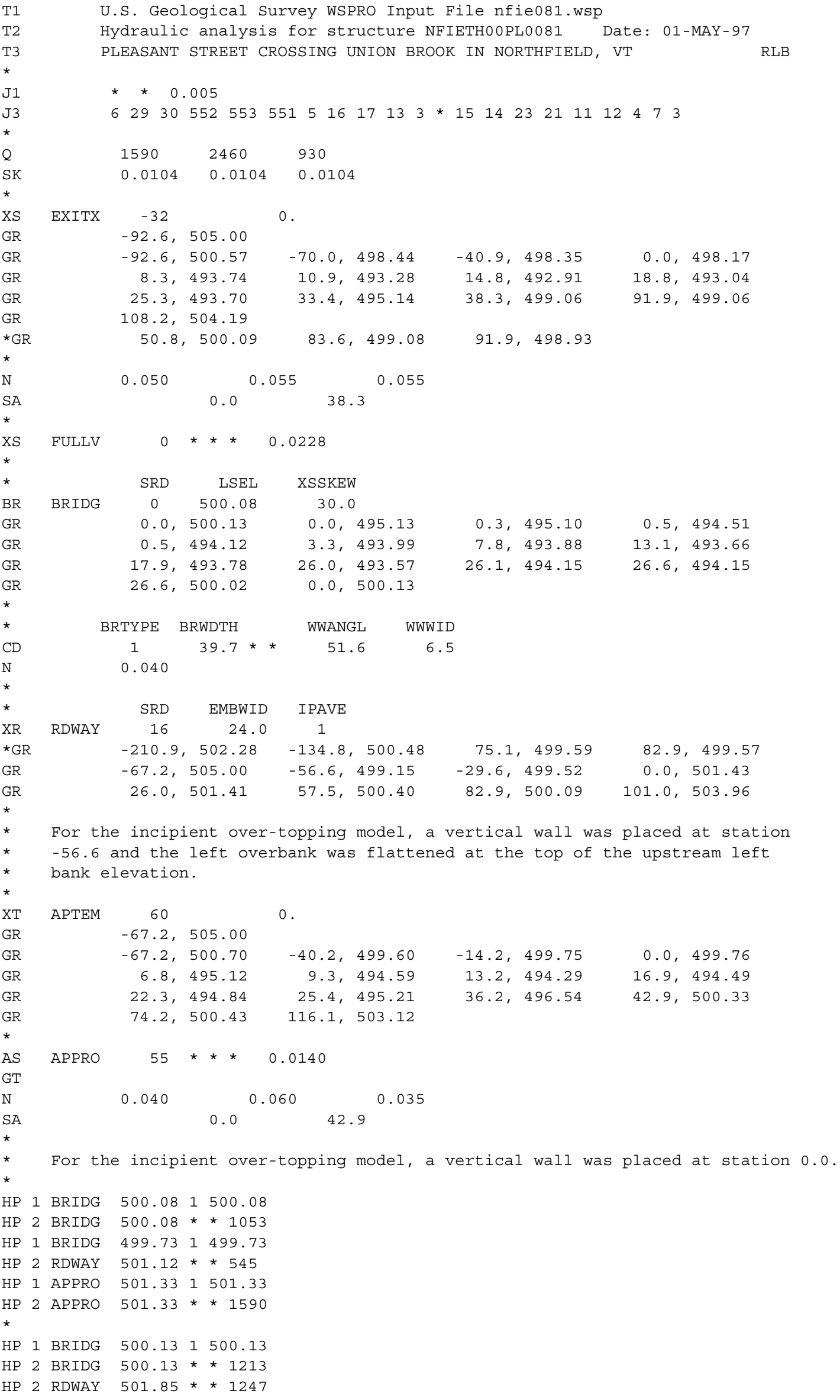




\section{APPENDIX B: \\ WSPRO OUTPUT FILE}




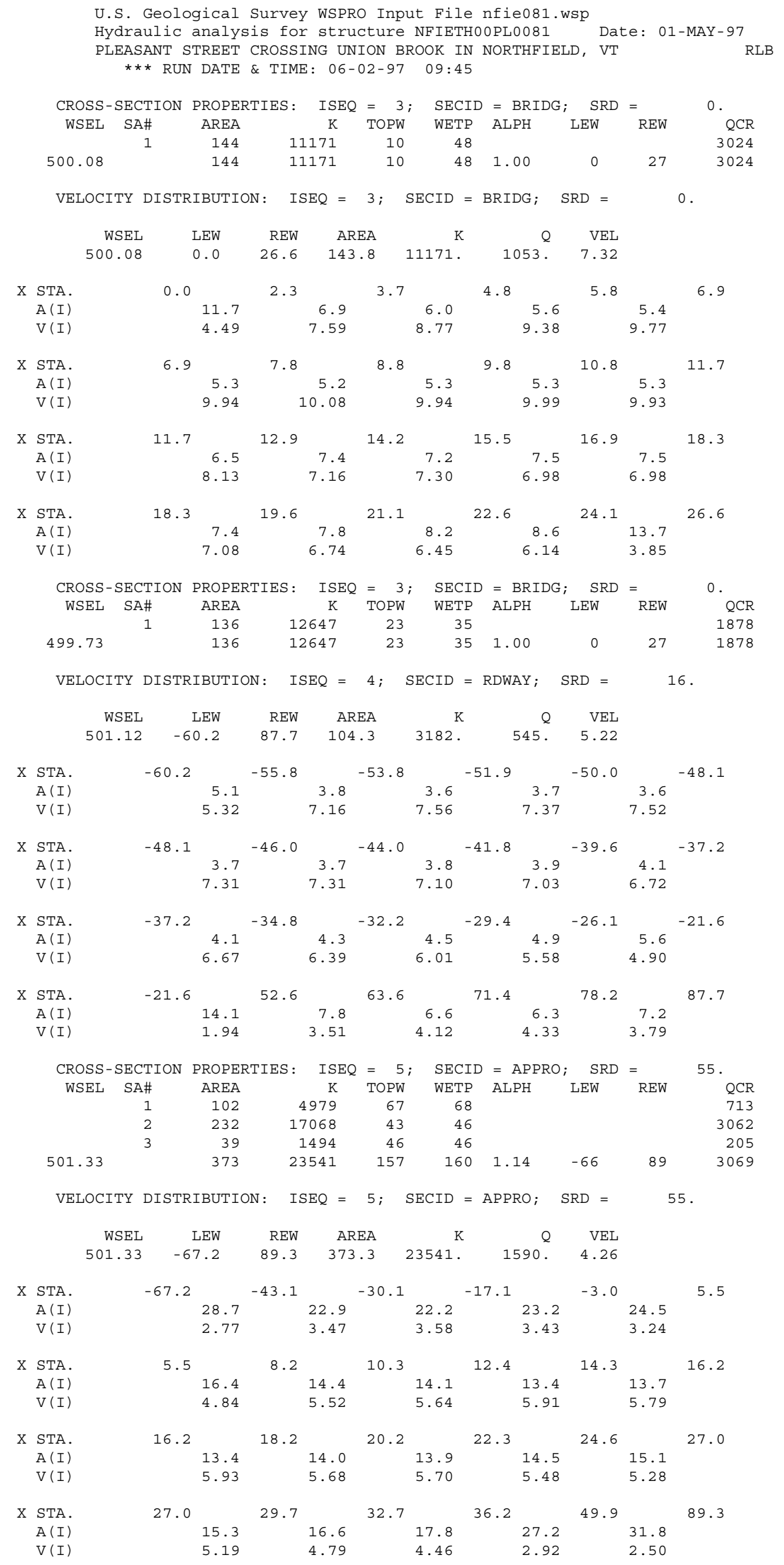


WSPRO OUTPUT FILE (continued)

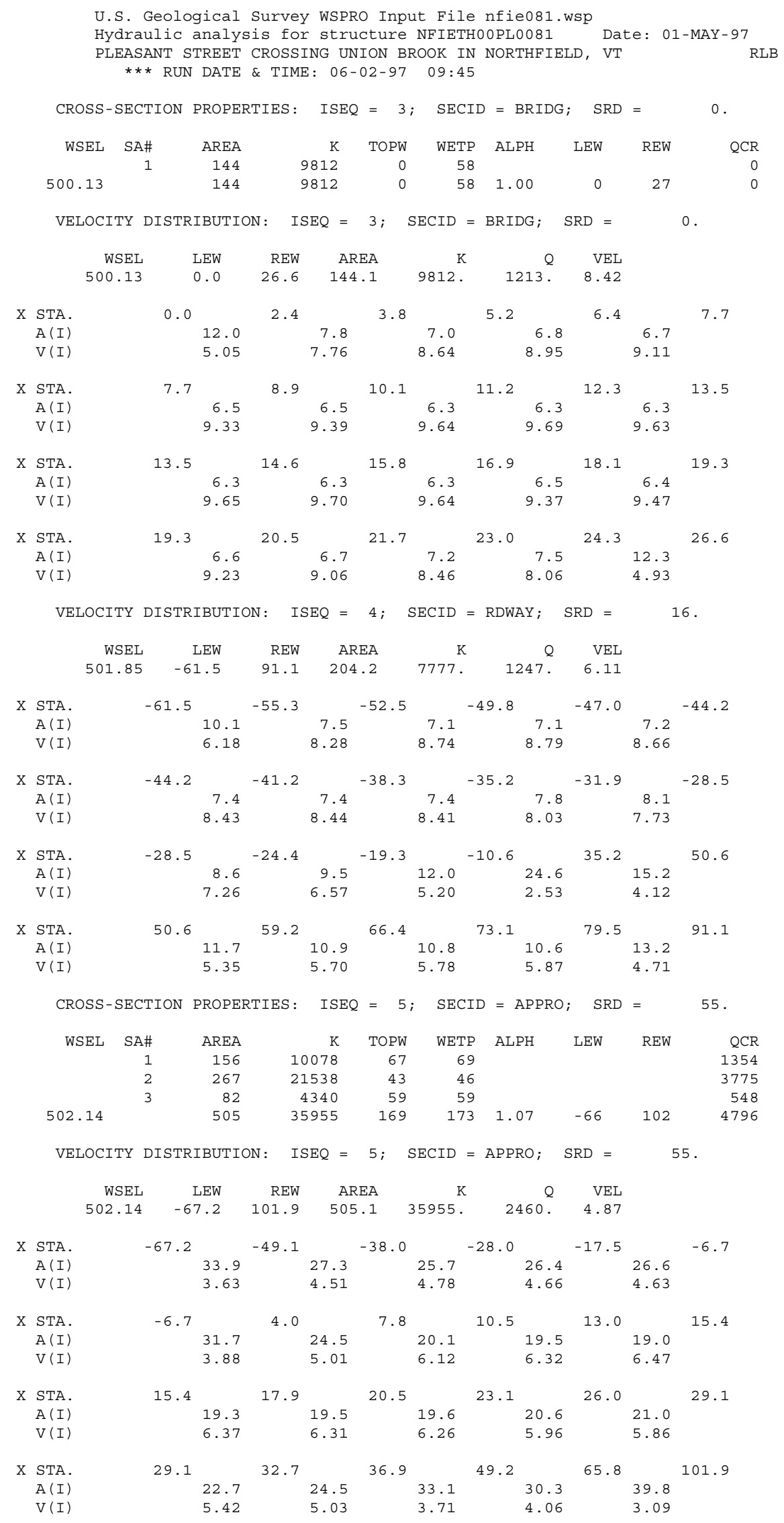


WSPRO OUTPUT FILE (continued)

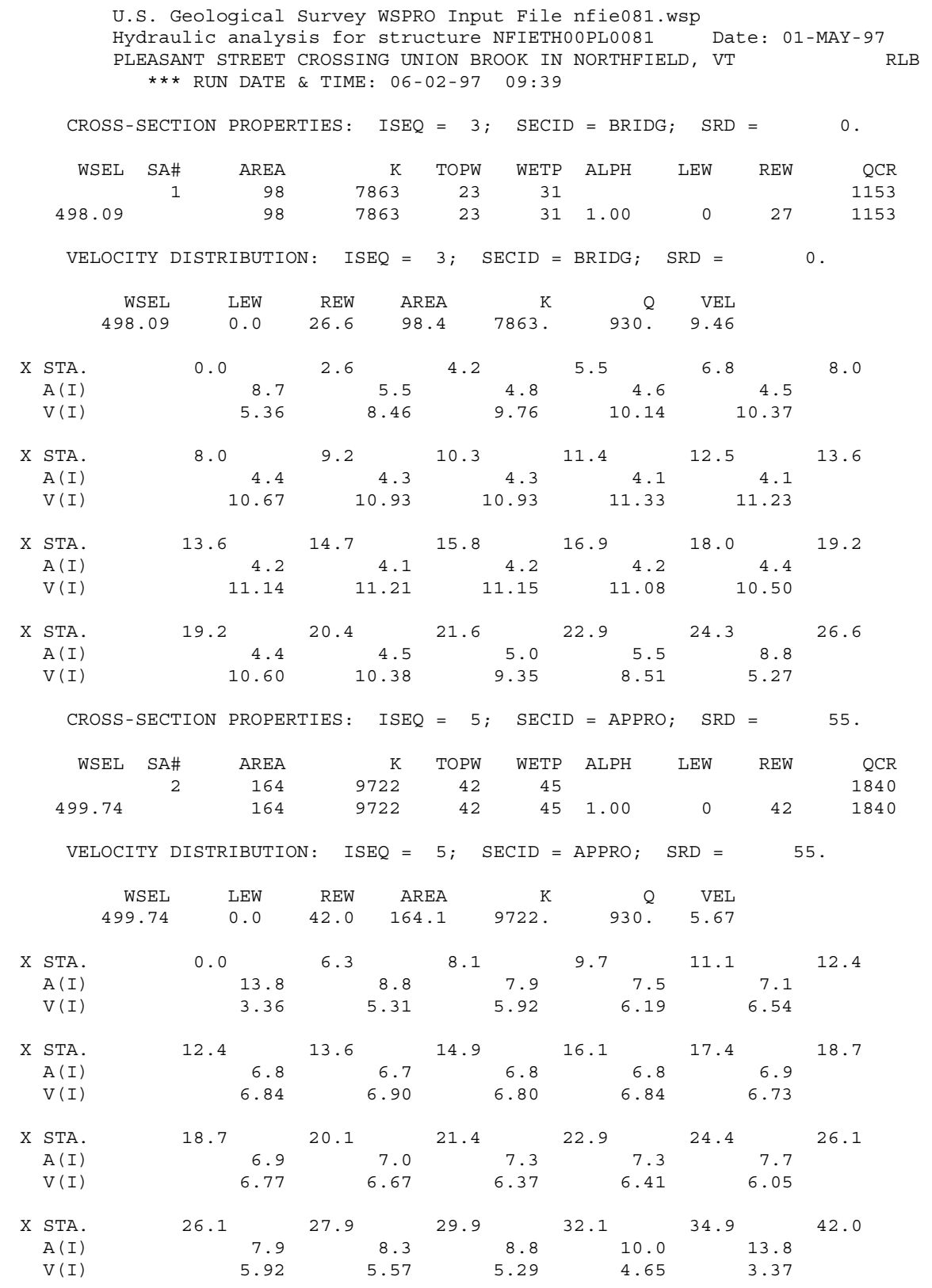


WSPRO OUTPUT FILE (continued)

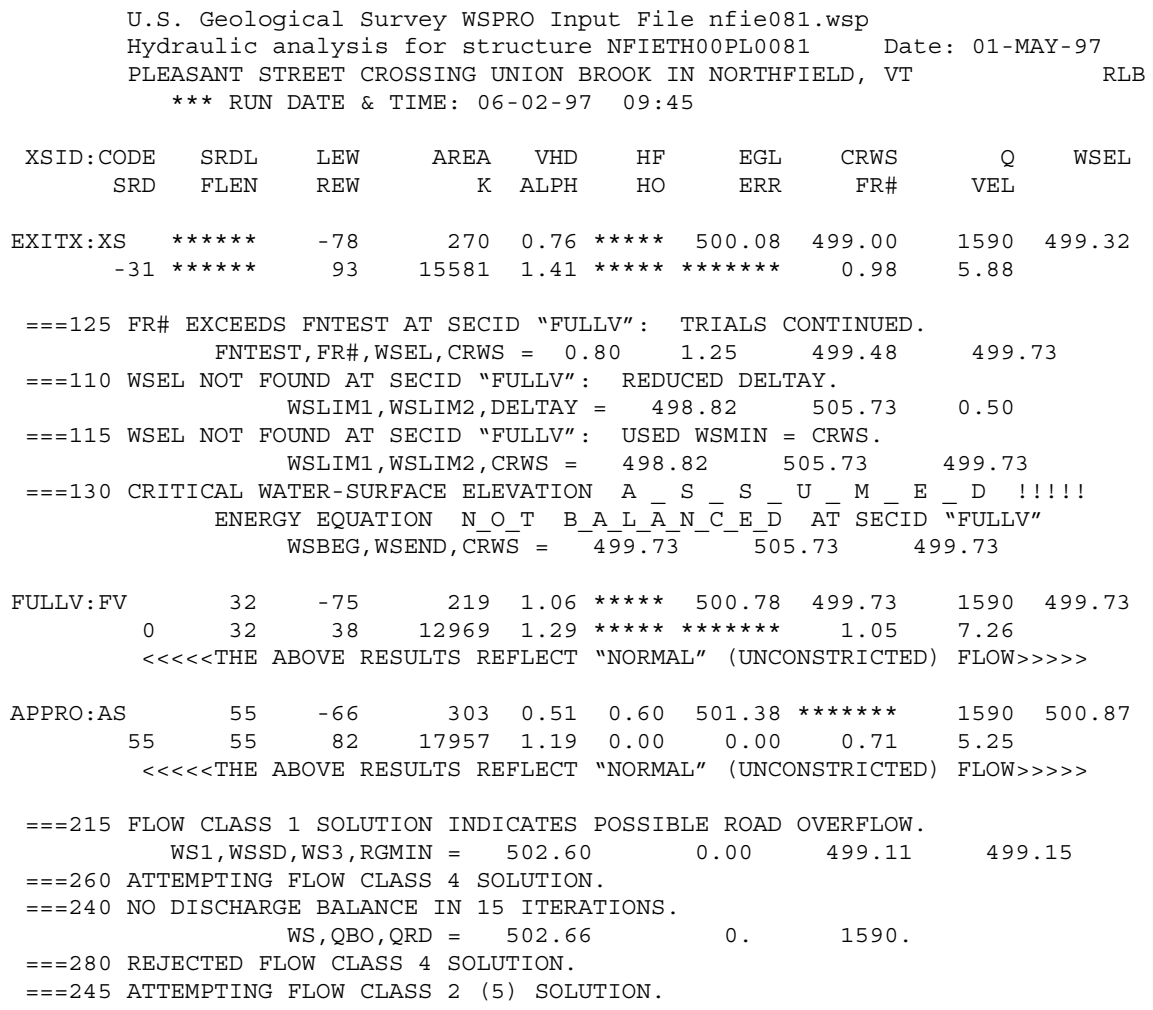

SECOND USER DEFINED TABLE.

$\begin{array}{lcrrrrrrrr}\text { XSID : CODE } & \text { CRWS } & \text { FR\# } & \text { YMIN } & \text { YMAX } & \text { HF } & \text { HO } & \text { VHD } & \text { EGL } & \text { WSEL } \\ \text { EXITX:XS } & 499.00 & 0.98 & 492.91 & 505.00 * * * * * * * * * * & 0.76 & 500.08 & 499.32 \\ \text { FULLV : FV } & 499.73 & 1.05 & 493.64 & 505.73 * * * * * * * * * * * & 1.06 & 500.78 & 499.73 \\ \text { BRIDG :BR } & 497.84 & 0.56 & 493.57 & 500.13 * * * * * * * * * * & 0.83 & 500.91 & 500.08 \\ \text { RDWAY : RG } & * * * * * * * * * * * * * * * & 499.15 & 505.00 & 0.14 * * * * * * & 0.32 & 501.51 & 501.12 \\ \text { APPRO :AS } & 499.34 & 0.52 & 494.22 & 504.93 & 0.12 & 0.00 & 0.32 & 501.65 & 501.33\end{array}$


WSPRO OUTPUT FILE (continued)

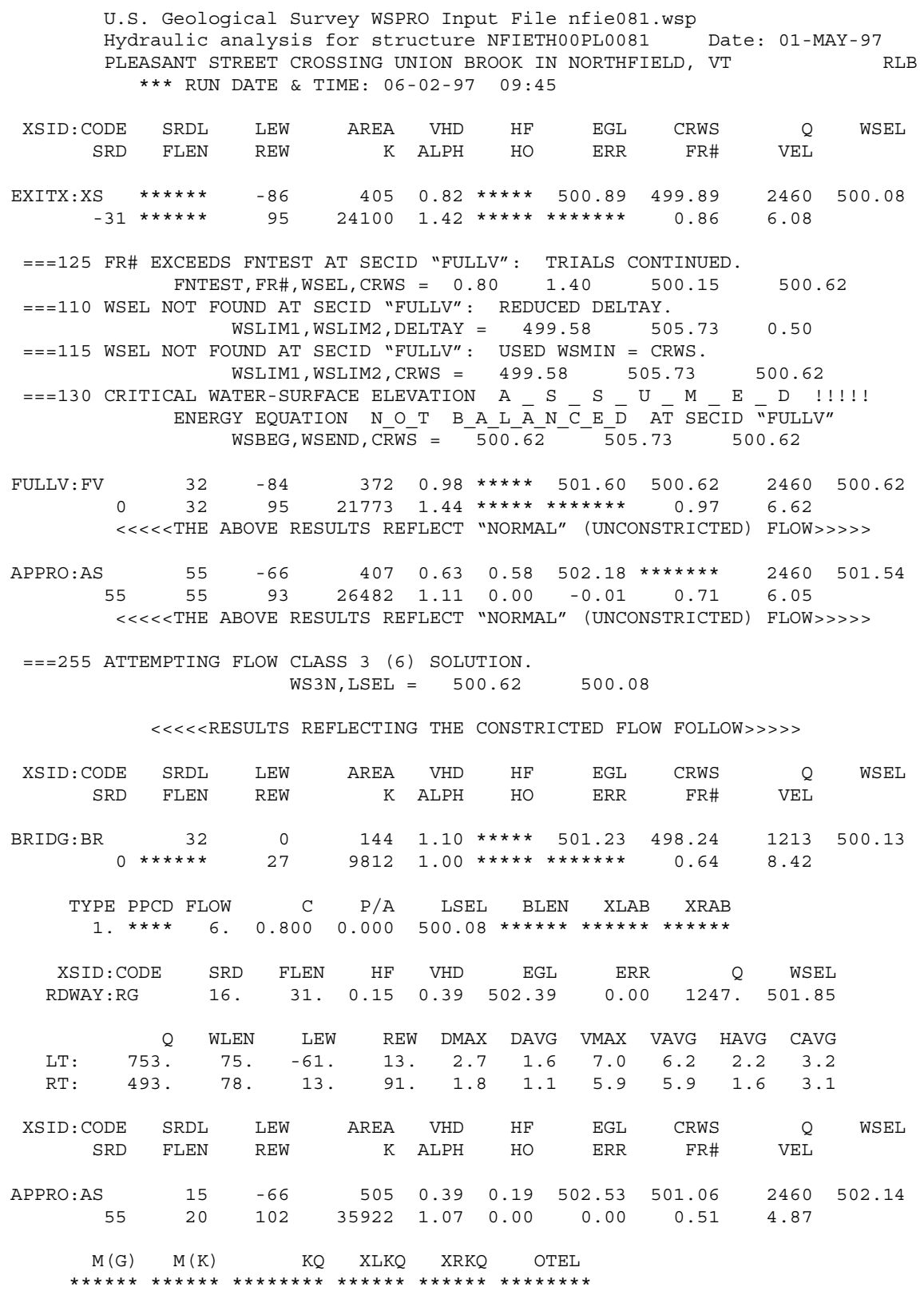

$<<<<$ END OF BRIDGE COMPUTATIONS $>>>>>$

FIRST USER DEFINED TABLE.

\begin{tabular}{|c|c|c|c|c|c|c|c|c|}
\hline XSID : CODE & SRD & LEW & REW & Q & K & AREA & VEL & WSEL \\
\hline EXITX:XS & -32. & -87 & 95. & 2460 . & 24100 & 405 & 6.08 & 500.08 \\
\hline FULLV : FV & 0 . & -85. & 95. & 2460 . & 21773 & 372 . & 6.62 & 500.62 \\
\hline BRIDG : BR & 0 . & 0 . & 27. & 1213. & 9812. & 144 . & 8.42 & 500.1 \\
\hline RDWAY : RG & $16 . *$ & $\star \star \star \star * *$ & 753. & 1247. & 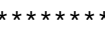 & $\star \star \star \star \star *$ & 1.00 & 501.8 \\
\hline APPRO : AS & 55. & -67 & 102. & 2460 . & 35922 . & 505. & 4.87 & 502.14 \\
\hline XSID : CODE & XLKQ & XRKQ & & & & & & \\
\hline
\end{tabular}

SECOND USER DEFINED TABLE.

\begin{tabular}{|c|c|c|c|c|c|c|c|c|c|}
\hline XSID : CODE & CRWS & FR\# & YMIN & YMAX & $\mathrm{HF}$ & $\mathrm{HO}$ & VHD & EGL & WSE \\
\hline EXITX:XS & 499.89 & 0.86 & 492.91 & $505.00 *$ & $\star \star \star *$ & 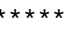 & 0.82 & 500.89 & 500 \\
\hline FULLV : FV & 500.62 & 0.97 & 493.64 & $505.73 *$ & $\star \star \star \star \star \star \star * *$ & 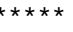 & 0.98 & 501.60 & 500. \\
\hline BRIDG : BR & 498.24 & 0.64 & 493.57 & $500.13 *$ & $k * \star * * * *$ & 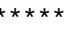 & 1.10 & 501.23 & 500 \\
\hline RDWAY : RG & $\star * \star * * * * * *$ & $\star \star \star * * *$ & 499.15 & 505.00 & $0.15 * x$ & $\star * * * *$ & 0.39 & 502.39 & 501. \\
\hline APPRO: AS & 501.06 & 0.51 & 494.22 & 504.93 & 0.19 & 0.00 & 0.39 & 502.53 & 502. \\
\hline
\end{tabular}


WSPRO OUTPUT FILE (continued)

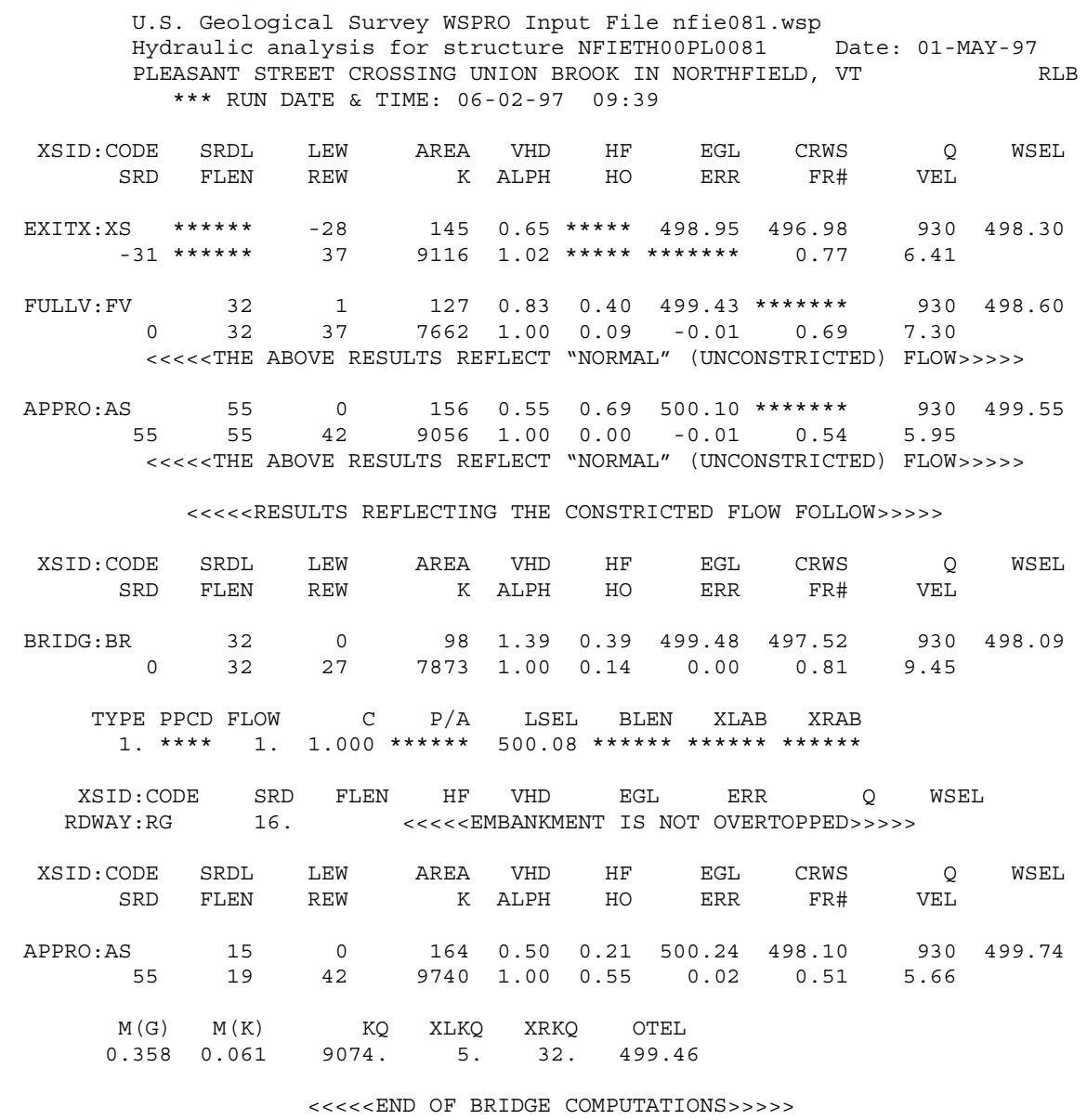

FIRST USER DEFINED TABLE.

\begin{tabular}{|c|c|c|c|c|c|c|c|c|}
\hline XSID : CODE & SRD & LEW & REW & $\mathrm{Q}$ & $\mathrm{K}$ & AREA & VEL & WSEL \\
\hline EXITX:XS & -32 & -29 & 37. & 930. & 9116. & 145 . & 6.41 & 498.30 \\
\hline FULLV : FV & 0. & 1. & 37. & 930. & 7662 . & 127 & 7.30 & 498.60 \\
\hline BRIDG : BR & 0 . & 0 . & 27. & 930. & 7873. & 98. & 9.45 & 498.09 \\
\hline RDWAY : RG & \multicolumn{3}{|c|}{$16 . * * * * * * * * * * * * * *$} & \multicolumn{3}{|c|}{$0 . * * * * * * * * * * * * * * * * * *$} & \multicolumn{2}{|c|}{$1.00 * * * * * * * *$} \\
\hline APPRO : AS & 55. & 0 . & 42 . & 930. & 9740. & 164 . & 5.66 & 499.74 \\
\hline XSID : CODE & XLKQ & XRKQ & & & & & & \\
\hline APPRO : AS & 5. & 32. & 9074 & & & & & \\
\hline
\end{tabular}

SECOND USER DEFINED TABLE.

\begin{tabular}{|c|c|c|c|c|c|c|c|c|c|}
\hline XSID : CODI & CRWS & FR\# & YMIN & YMAX & $\mathrm{HF}$ & $\mathrm{HO}$ & VHD & EGL & WSEL \\
\hline EXITX:XS & 496.98 & .77 & 492.91 & $505.00 *$ & 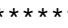 & *** & 0.65 & 498.95 & 498.30 \\
\hline ELLV : FV & 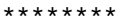 & .69 & 493.64 & 505.73 & 0.40 & 0.09 & 0.83 & 43 & 98.60 \\
\hline BRIDG : BR & 497.52 & 0.81 & 493.57 & 500.13 & 0.39 & 0.14 & 1.39 & 499.48 & 498.09 \\
\hline RDWAY : RG & 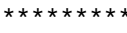 & $\star \star \star \star *$ & 499.76 & $505.00 *$ & $\star * *$ & $\star \star *$ & $\star \star \star *$ & 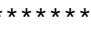 & $\star * * *$ \\
\hline PPRO : AS & 498.10 & 0.51 & 494.22 & 504.93 & 0.21 & 0.55 & 0.50 & 500.24 & 499 \\
\hline
\end{tabular}




\section{APPENDIX C:}

\section{BED-MATERIAL PARTICLE-SIZE DISTRIBUTION}




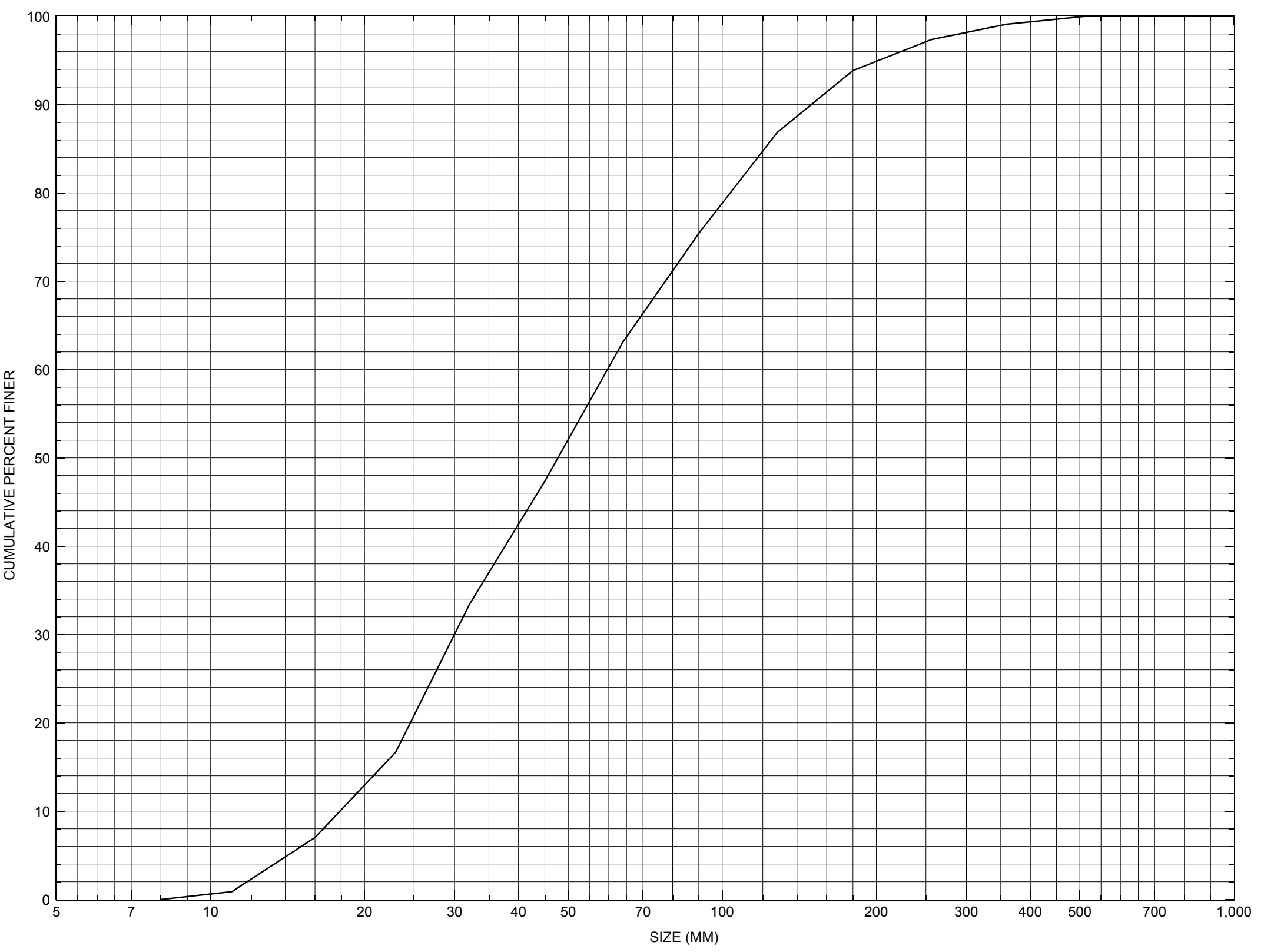

Appendix C. Bed material particle-size distribution for a pebble count in the channel approach of structure NFIETH00PL0081, in Northfield, Vermont. 


\section{APPENDIX D: \\ HISTORICAL DATA FORM}




\section{Structure Number NFIETH00PL0081}

\section{General Location Descriptive}

Data collected by (First Initial, Full last name) $\underline{\mathbf{L}}$. Medalie

Date $(M M / D D / Y Y) \_10 / 13 / \underline{95}$

Highway District Number (I - 2; nn) $\mathbf{0 6}$

Town (FIPS place code; I - 4; nnnnn) $\mathbf{5 0 2 0 0}$

Waterway (I - 6) UNION BROOK

Route Number C30PL

Topographic Map Northfield

Latitude (I - 16; nnnn.n) $\mathbf{4 4 0 9 1}$
County (FIPS county code; I - 3; nnn)

Mile marker (I - 11; nnn.nnn) $\mathbf{0 0 0 0 0 0}$

Road Name ( $($ - 7): PLEASANT STREET

Vicinity (I - 9) 0.02 MI TO JCT W UNION S

Hydrologic Unit Code: -

Longitude (i - 17; nnnnn.n) $\mathbf{7 2 3 9 7}$

\section{Select Federal Inventory Codes}

FHWA Structure Number (I - 8) $\mathbf{1 0 1 2 1 3 0 0 8 1 1 2 1 3}$

Maintenance responsibility $(I-21 ; n n) \quad \mathbf{0 3} \quad$ Maximum span length $(I-48 ; n n n n) \underline{\mathbf{0 0 2 9}}$

Year built (I - 27; YYYY) 1970

Structure length (I - 49; nnnnnn) $\underline{\mathbf{0 0 0 0 3 4}}$

Average daily traffic, ADT (I - 29; nnnnnn) 000150

Deck Width (I - 52; nn.n) $\mathbf{2 4 0}$

Year of ADT (I - 30; YY) $\mathbf{9 2}$

Channel \& Protection $(I-61 ; n) \underline{6}$

Opening skew to Roadway $(I-34 ; n n) \quad \mathbf{3 0}$

Waterway adequacy $(I-71 ; n)$

Operational status $(I-41 ; X) \quad \mathbf{A}$

Underwater Inspection Frequency $(I-92 B ; X Y Y) \_\mathbf{N}$

Structure type (I- 43; nnn) $\mathbf{3 0 2}$

Year Reconstructed (I - 106) $\mathbf{0 0 0 0}$

Approach span structure type (I - 44; nnn) $\mathbf{0 0 0}$

Clear span (nnn.n ft) $\mathbf{2 5 . 4}$

Number of spans (I - 45; nnn) $\underline{\mathbf{0 0 1}}$

Vertical clearance from streambed (nnn.n ft) $\underline{\mathbf{5 . 7}}$

Number of approach spans (I - 46; nnnn) $\underline{\mathbf{0 0 0 0}}$ Waterway of full opening $\left(n n n . n \mathrm{ft}^{2}\right) \underline{\mathbf{1 4 4 . 1}}$

Comments:

According to the structural inspection report dated 8/17/94, the deck is asphalt filled wrinkled tin. Bridge guard rails are fascia mounted, painted I-beam posts with 2 painted wood plank rails. The RABUT, its wingwalls and footing are concrete. The LABUT and its upstream wingwall are concrete faced laid-up stone walls. The downstream left wingwall is a laid-up stone wall with a concrete footing. Both abutments have wood plank backwalls. The LABUT and its upstream wingwall have cracks and leaks overall. Small concrete spalls or popouts are present under several of the beams along the top of each abutment. The RABUT and its wingwalls have a few fine cracks and leaks. (Continued p. 33) 


\section{Bridge Hydrologic Data}

Is there hydrologic data available? $\underline{\mathbf{N}}$ if No, type ctrl-n $h \quad$ VTAOT Drainage area $\left(m i^{2}\right)$ : -

Terrain character:

Stream character \& type: -

Streambed material:

Discharge Data (cfs):

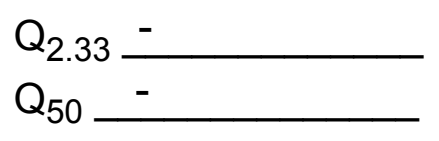

Record flood date $(M M / D D / Y Y):-{ }^{\prime}-$
Estimated Discharge $(c f s):-$

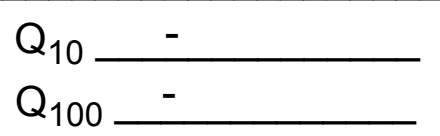

$\mathrm{Q}_{25}$

Water surface elevation $(f t):-$ $(\mathrm{ft} / \mathrm{s}):$

Ice conditions (Heavy, Moderate, Light) : -

Debris (Heavy, Moderate, Light):

The stage increases to maximum highwater elevation (Rapidly, Not rapidly):

The stream response is (Flashy, Not flashy):

Describe any significant site conditions upstream or downstream that may influence the stream's stage: -

Watershed storage area (in percent):

The watershed storage area is: - (1-mainly at the headwaters; 2- uniformly distributed; 3-immediatly upstream oi the site)

Water Surface Elevation Estimates for Existing Structure:

\begin{tabular}{|l|l|l|l|l|l|}
\hline Peak discharge frequency & $Q_{2.33}$ & $Q_{10}$ & $Q_{25}$ & $Q_{50}$ & $Q_{100}$ \\
Water surface elevation (ft)) & - & - & - & - & - \\
Velocity (ft/sec) & - & - & - & - & - \\
\hline
\end{tabular}

Long term stream bed changes: -

Is the roadway overtopped below the $\mathrm{Q}_{100}$ ? (Yes, No, Unknown): $\mathbf{U}$ Frequency: -

Relief Elevation $(f t)$ :

Discharge over roadway at $Q_{100}\left(f t^{3} / \mathrm{sec}\right)$ :

Are there other structures nearby? (Yes, No, Unknown): Upstream distance (miles): Town: If No or Unknown, type ctrl-n os Highway No. :Structure No. : Year Built:

Clear span (ft): Clear Height $(f t)$ : Full Waterway $\left(f^{2}\right)$ : 
Downstream distance (miles): Town: Year Built:

Highway No. : Structure No. : Structure Type:

Clear span (ft): Clear Height $(f t)$ : Full Waterway $\left(f^{2}\right)$ :

Comments:

Each abutment has a buildup of gravel and debris on its top. Stones and boulders are showing along the US \& DS channel banks.

\section{USGS Watershed Data}

Watershed Hydrographic Data

Drainage area $(D A)$

Watershed storage (ST)

Bridge site elevation $\mathbf{7 2 0}$ $\mathrm{mi}^{2}$ Lake/pond/swamp area 0.005 $\mathrm{mi}^{2}$

Main channel length $\mathbf{5 . 5 6}$ Headwater elevation 2386 $\mathrm{ft}$ $10 \%$ channel length elevation $\quad \mathbf{7 8 0}$ $\mathrm{ft} \quad 85 \%$ channel length elevation 1770 $\mathrm{ft}$

Main channel slope $(S)$

(S) 237.41 $\mathrm{ft} / \mathrm{mi}$

Watershed Precipitation Data

Average site precipitation in Average headwater precipitation in

Maximum 2yr-24hr precipitation event $(124,2)$ in

Average seasonal snowfall (Sn) $\mathrm{ft}$ 


\section{Bridge Plan Data}

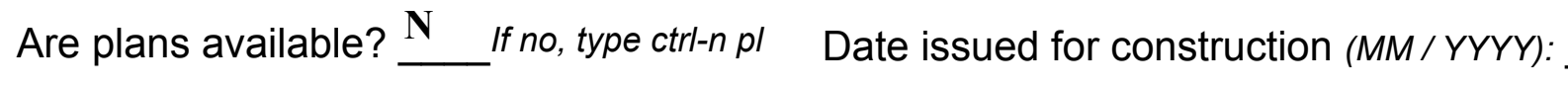

Project Number

Minimum channel bed elevation:

Low superstructure elevation: USLAB DSLAB USRAB DSRAB Benchmark location description:

NO BENCKMARK INFORMATION

Reference Point (MSL, Arbitrary, Other): Datum (NAD27, NAD83, Other):

Foundation Type: 4

If 1 : Footing Thickness

If 2: Pile Type:

If 3: Footing bottom elevation:

Is boring information available? $\mathbf{N}$

Foundation Material Type: $\mathbf{3}$

(1-Spreadfooting; 2-Pile; 3- Gravity; 4-Unknown)

Footing bottom elevation: -

Briefly describe material at foundation bottom elevation or around piles:

NO DRILL BORING INFORMATION

Comments: 


\section{Cross-sectional Data}

Is cross-sectional data available? $\mathbf{N}$ If no, type ctrl-n xs

Source (FEMA, VTAOT, Other)? Comments:

\section{NO CROSS SECTIONAL INFORMATION}

\begin{tabular}{|l|l|l|l|l|l|l|l|l|l|l|l|}
\hline Station & - & - & - & - & - & - & - & - & - & - & - \\
\hline Feature & - & - & - & - & - & - & - & - & - & - & - \\
\hline $\begin{array}{l}\text { Low cord } \\
\text { elevation }\end{array}$ & - & - & - & - & - & - & - & - & - & - & - \\
\hline $\begin{array}{l}\text { Bed } \\
\text { elevation }\end{array}$ & - & - & - & - & - & - & - & - & - & - & - \\
\hline $\begin{array}{l}\text { Low cord to } \\
\text { bed length }\end{array}$ & - & - & - & - & - & - & - & - & - & - & - \\
\hline Station & - & - & - & - & - & - & - & - & - & - & - \\
\hline Feature & - & - & - & - & - & - & - & - & - & - & - \\
\hline $\begin{array}{l}\text { Low cord } \\
\text { elevation }\end{array}$ & - & - & - & - & - & - & - & - & - & - & - \\
\hline $\begin{array}{l}\text { Bed } \\
\text { elevation }\end{array}$ & - & - & - & - & - & - & - & - & - & - & - \\
\hline $\begin{array}{l}\text { Low cord to } \\
\text { bed length }\end{array}$ & - & - & - & - & - & - & - & - & - & - & - \\
\hline
\end{tabular}

Source (FEMA, VTAOT, Other)?

Comments: -

\begin{tabular}{|l|l|l|l|l|l|l|l|l|l|l|l|}
\hline Station & - & - & - & - & - & - & - & - & - & - & - \\
\hline Feature & - & - & - & - & - & - & - & - & - & - & - \\
\hline $\begin{array}{l}\text { Low cord } \\
\text { elevation }\end{array}$ & - & - & - & - & - & - & - & - & - & - & - \\
\hline $\begin{array}{l}\text { Bed } \\
\text { elevation }\end{array}$ & - & - & - & - & - & - & - & - & - & - & - \\
\hline $\begin{array}{l}\text { Low cord to } \\
\text { bed length }\end{array}$ & - & - & - & - & - & - & - & - & - & - & - \\
\hline Station & - & - & - & - & - & - & - & - & - & - & - \\
\hline Feature & - & - & - & - & - & - & - & - & - & - & - \\
\hline $\begin{array}{l}\text { Low cord } \\
\text { elevation }\end{array}$ & - & - & - & - & - & - & - & - & - & - & - \\
\hline $\begin{array}{l}\text { Bed } \\
\text { elevation }\end{array}$ & - & - & - & - & - & - & - & - & - & - & - \\
\hline $\begin{array}{l}\text { Low cord to } \\
\text { bed length }\end{array}$ & - & - & - & - & - & - & - & - & - & - & - \\
\hline
\end{tabular}




\section{APPENDIX E: \\ LEVEL I DATA FORM}


U. S. Geological Survey

Bridge Field Data Collection and Processing Form

Qa/Qc Check by: RB Date: $09 / 23 / 96$

\section{Structure Number NFIETH00PL0081}

Computerized by: $\underline{\mathbf{R B}}$ Date: $09 / 23 / 96$

Reviewd by: $\quad$ RB Date: $\underline{06 / 03 / 97}$

\section{A. General Location Descriptive}

1. Data collected by (First Initial, Full last name) L. MEDALIE

2. Highway District Number 06

County (023) WASHINGTON

Waterway $(l$ - 6) UNION BROOK

Route Number C30PL

3. Descriptive comments:

Located 0.02 miles from the junction with Union Street.
Mile marker 00000

Town (50200) NORTHFIELD

Road Name PLEASANT STREET

Hydrologic Unit Code:

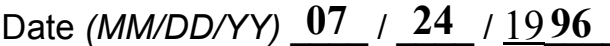

\section{B. Bridge Deck Observations}
4. Surface cover... LBUS 2
RBUS 2
LBDS 2
RBDS 2
Overall 2

(2b us, ds,lb,rb: 1- Urban; 2- Suburban; 3- Row crops; 4- Pasture; 5- Shrub- and brushland; 6- Forest; 7- Wetland)
5. Ambient water surface... US $\underline{2}$
UB 2
DS $\underline{2}$
(1- pool; 2- riffle)

6. Bridge structure type 1 (1- single span; 2- multiple span; 3- single arch; 4- multiple arch; 5-cylindrical culvert; 6- box culvert; or 7-other)
7. Bridge length $\mathbf{3 4}$ (feet)
Span length 29
(feet)
Bridge width 24 (feet)

\section{Road approach to bridge:}
8. LB 1 RB 1
( 0 even, 1- lower, 2- higher)
9. $\mathrm{LB}$ RB 1
(1-Paved, 2- Not paved)

10. Embankment slope (run / rise in feet / foot):

US left

US right

\begin{tabular}{|c|c|c|c|}
\hline \multicolumn{2}{|c|}{ Protection } & \multirow{2}{*}{ 13.Erosion } & 14.Severity \\
\hline 11.Type & 12.Cond. & - & $\underline{\mathbf{3}}$ \\
\hline $\mathbf{0}$ & - & $\underline{\mathbf{3}}$ & $\underline{\mathbf{2}}$ \\
\hline $\mathbf{0}$ & - & $\underline{\mathbf{3}}$ & $\underline{\mathbf{2}}$ \\
\hline $\mathbf{0}$ & - & $\mathbf{2}$ & $\mathbf{1}$ \\
\hline $\mathbf{0}$ & - & $\underline{\mathbf{2}}$ & $\mathbf{-}$ \\
\hline
\end{tabular}

Bank protection types: 0- none; 1- < 12 inches;

2- < 36 inches; 3- < 48 inches;

4- < 60 inches; 5- wall / artificial levee

Bank protection conditions: 1- good; 2- slumped;

3- eroded; 4- failed

Erosion: 0 - none; 1- channel erosion; 2 -

road wash; 3- both; 4- other

Erosion Severity: 0 - none; 1- slight; 2- moderate; 3- severe

\section{Channel approach to bridge (BF):}

15. Angle of approach: $\mathbf{2 0}$

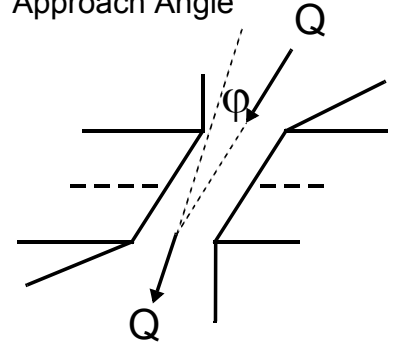

17. Channel impact zone 1:

Where? LB $(L B, R B)$

Range? 19 feet US

Channel impact zone 2:

Where? $(L B, R B)$

Range? - $\quad$ feet -

(US, UB, DS) to Impact Severity: 0- none to very slight; 1- Slight; 2-Moderate; 3- Severe feet -

16. Bridge skew: 25 Bridge Skew Angle

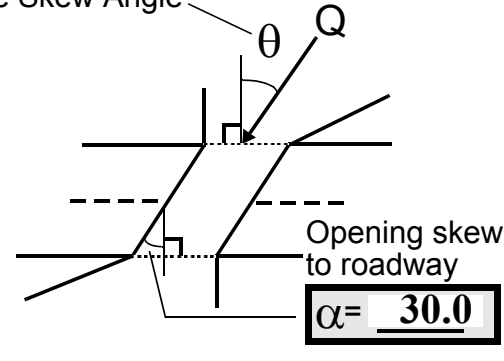

\section{Exist? $\mathbf{Y}(Y$ or $N)$}

Severity 1

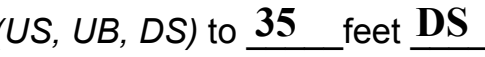

Exist? $\mathbf{N}(Y$ or $N)$

Severity - 
18. Bridge Type: 1a

1a- Vertical abutments with wingwalls

1 b- Vertical abutments without wingwalls

2- Vertical abutments and wingwalls, sloping embankment Wingwalls perpendicular to abut. face

3- Spill through abutments

4- Sloping embankment, vertical wingwalls and abutments $1 \mathrm{~b}$ without wingwalls Wingwall angle less than $90^{\circ}$.
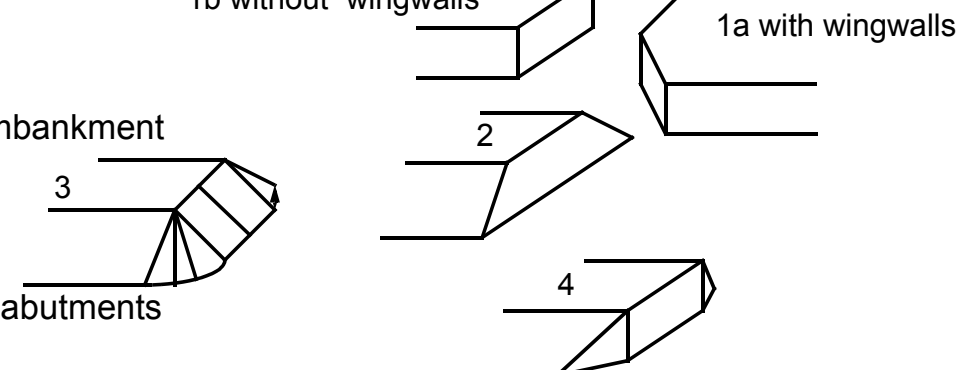

19. Bridge Deck Comments (surface cover variations, measured bridge and span lengths, bridge type variations, approach overflow width, etc.)

11. On the left bank DS there is a laid-up stone wall between the wingwall and the channel and is described as wingwall protection.

13. The road wash erosion is most pronounced around the ends of the wingwalls.

7. Values are from the VT AOT files. Measured bridge length is $33.5 \mathrm{ft}$, span length is $26.6 \mathrm{ft}$, and bridge width is $24 \mathrm{ft}$.

3. An employee of the highway department said a water main is buried $2 \mathrm{ft}$ deep under the channel $8 \mathrm{ft}$ US of the bridge and has never been exposed. The highway department plans on putting new abutment faces and footings on this bridge. There have been many ice jams where the water flowed over Union Street and did not impact the bridge. Also, the bridge just DS of this bridge has lots of scour problems.

\section{Upstream Channel Assessment}

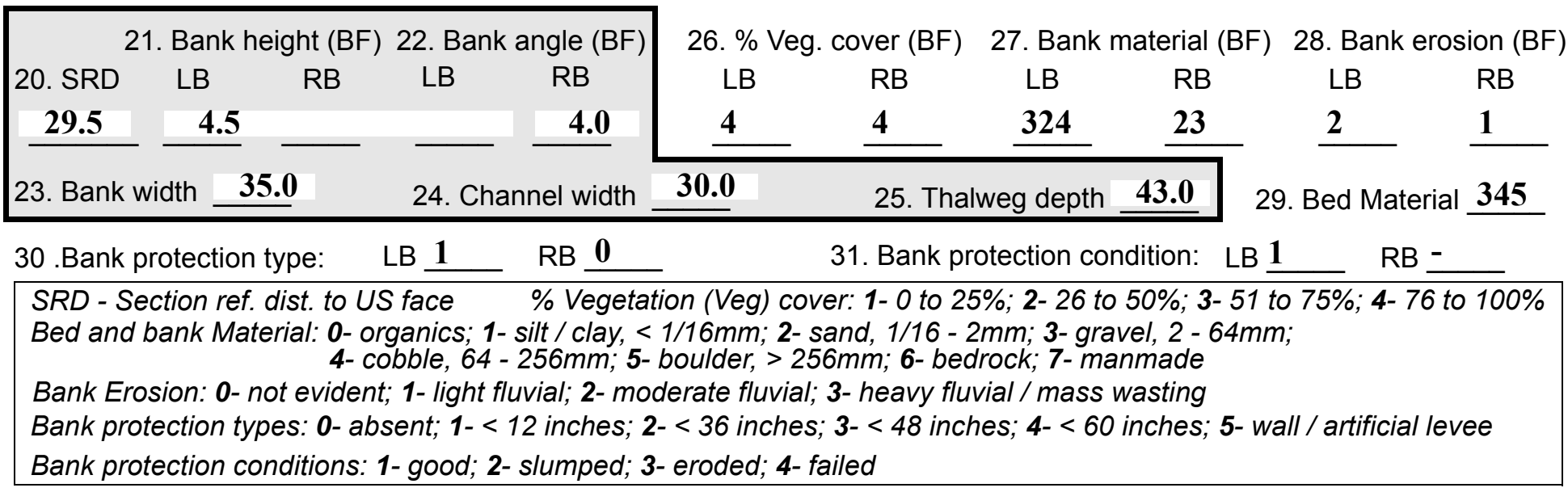

32. Comments (bank material variation, minor inflows, protection extent, etc.):

26. On the left bank there is a single large maple at $41 \mathrm{ft}$ US that has a $20 \mathrm{ft}$ crown that provides maximum coverage. Upstream and downstream of this tree there are no other large trees, only shrubs on the bank.

30. A single granite slab, $5 \mathrm{ft} \times 1.25 \mathrm{ft} \times 0.75 \mathrm{ft}$, is resting on the left bank at $26 \mathrm{ft}$ US. It is the only large piece of protection. Smaller pieces of stone, $<12 \mathrm{in}$, are placed along the bank to at least $200 \mathrm{ft}$ US. The bank also acts as the road embankment for Union Street.

A 7 in diameter culvert that passes under Union Street enters on the left bank at 29 ft US. 
36. Point bar extent: $\underline{\mathbf{7 2}}$ feet $\underline{\mathbf{U S}}$ (US, UB) to $\underline{\mathbf{1 0}}$ feet $\underline{\mathbf{U B}}$ (US, UB, DS) positioned $\underline{\mathbf{5 0}} \%$ LB to $\underline{\mathbf{9 5}} \%$ RB

37. Material: $\mathbf{3 2 4}$

38. Point or side bar comments (Circle Point or Side; Note additional bars, material variation, status, etc.):

Point bar is $\mathbf{9 0 \%}$ covered with grass.

39. Is a cut-bank present? $\mathbf{Y}$ ( $Y$ or if $N$ type ctrl-n $c b)$

40. Where? $\underline{\mathbf{L B}}$ (LB or RB)

41. Mid-bank distance: 175

42. Cut bank extent: $\underline{\mathbf{2 5 0}}$ feet $\underline{\mathrm{US}}$ (US, UB) to $\underline{\mathbf{1 9}}$ feet $\underline{\mathbf{U S}}$ (US, UB, DS)

43. Bank damage: 1

(1- eroded and/or creep; 2- slip failure; 3- block failure)

44. Cut bank comments (eg. additional cut banks, protection condition, etc.):

The stream makes a long gradual bend that impacts the left bank.

\section{Is channel scour present? $\mathbf{Y}$ ( $Y$ or if $N$ type ctrl-n cs)}

47. Scour dimensions: Length 7 Width $\underline{3}$ Depth : $\mathbf{0 . 5}$

46. Mid-scour distance: 8

48. Scour comments (eg. additional scour areas, local scouring process, etc.):

Local channel scour at the US bridge face.

\section{Are there major confluences? $\mathbf{N}$}

51. Confluence 1: Distance Confluence 2: Distance -

52. Enters on -

Enters on -

54. Confluence comments (eg. confluence name):

NO MAJOR CONFLUENCES
50. How many? -

53. Type(1- perennial; 2- ephemeral)

Type (1- perennial; 2- ephemeral) ( $L B$ or $R B)$

\section{Under Bridge Channel Assessment}

55. Channel restraint (BF)? LB 2

56. Height (BF)
LB RB
$\mathbf{2 9 . 5}-$
58. Bank width (BF) -
(1- natural bank; 2- abutment; 3- artificial levee)

Bed and bank Material: 0- organics; 1- silt / clay, < 1/16mm; 2- sand, 1/16 - 2mm; 3- gravel, 2 - 64mm; 4- cobble, 64 - 256mm; 5- boulder, > 256mm; 6- bedrock; 7- manmade

Bank Erosion: 0- not evident; 1- light fluvial; 2- moderate fluvial; 3- heavy fluvial / mass wasting

64. Comments (bank material variation, minor inflows, protection extent, etc.):

435 
65. Debris and Ice Is there debris accumulation?

67. Debris Potential (1- Low; 2- Moderate; 3- High)

69. Is there evidence of ice build-up? 2 (Y or $N)$

70. Debris and Ice Comments:

2
(Yor $N)$ 66. Where? $\mathbf{N}$

68. Capture Efficiency 2

(1- Upstream; 2- At bridge; 3-Both)

Ice Blockage Potential $\underline{\mathbf{Y}}$
(1- Low; 2- Moderate; 3- High)

(1-Low; 2- Moderate; 3- High)

\begin{tabular}{|l|c|c|c|c|c|c|c|c|}
\hline Abutments & $\begin{array}{c}\text { 71. Attack } \\
\angle \text { (BF) }\end{array}$ & $\begin{array}{c}72 \text {. Slope } \angle \\
\text { (Qmax) }\end{array}$ & $\begin{array}{c}\text { 73. Toe } \\
\text { loc. (BF) }\end{array}$ & $\begin{array}{c}\text { 74. Scour } \\
\text { Condition }\end{array}$ & $\begin{array}{c}75 . \text { Scour } \\
\text { depth }\end{array}$ & $\begin{array}{c}\text { 76. Exposure } \\
\text { depth }\end{array}$ & 77. Material & 78. Length \\
\hline LABUT & & $\mathbf{5}$ & $\mathbf{9 0}$ & $\mathbf{2}$ & $\mathbf{3}$ & $\mathbf{0 . 5}$ & $\mathbf{1}$ & $\mathbf{9 0 . 0}$ \\
\hline RABUT & $\mathbf{1}$ & $\mathbf{0}$ & $\mathbf{9 0}$ & & & $\mathbf{2}$ & $\mathbf{2}$ & $\mathbf{2 3 . 0}$ \\
\hline
\end{tabular}

Pushed: $L B$ or RB

Toe Location (Loc.): 0- even, 1- set back, 2- protrudes

Scour cond.: 0- not evident; 1- evident (comment); 2- footing exposed; 3-undermined footing; 4- piling exposed; 5- settled; 6- failed

Materials: 1- Concrete; 2- Stone masonry or drywall; 3- steel or metal; 4- wood

79. Abutment comments (eg. undermined penetration, unusual scour processes, debris, etc.):

0

0.5

1

74. The left abutment footing is undermined vertically up to $0.75 \mathrm{ft}$ in spots mostly at the US end. There is no undermining from the DS face to $12 \mathrm{ft}$ under the bridge except at the DS end where a $1.5 \mathrm{ft}$ section of the footing is missing and the bottom of the abutment is undermined $0.5 \mathrm{ft}$.

75. Average thalweg depth US is $0.5 \mathrm{ft}$. Scour at the left abutment extends from the DS end of the US left wingwall to $6 \mathrm{ft}$ under the bridge. It is $3.5 \mathrm{ft}$ at the widest point which is even with the US bridge face.

76. On the right abutment the footing is only exposed from the DS bridge face to $8 \mathrm{ft}$ under the bridge.

80. Wingwalls:

$\begin{array}{llll}\text { Exist? Material? } & \text { Scour } & \text { Scour Exposure } & \text { Angle? Length? } \\ & \text { Condition? depth? } & \text { depth? }\end{array}$

USLWW:

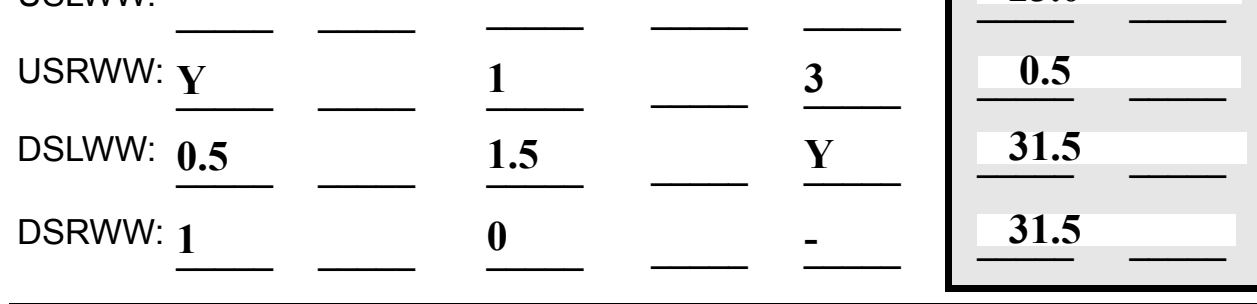

Wingwall materials: 1- Concrete; 2- Stone masonry or drywall; 3- steel or metal; 4- wood

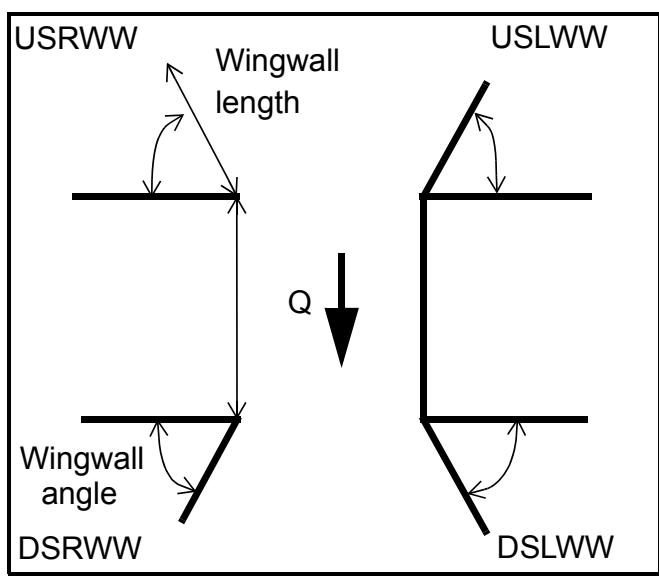

82. Bank / Bridge Protection:

\begin{tabular}{|l|l|l|l|l|l|l|c|c|}
\hline Location & USLWW & USRWW & LABUT & RABUT & LB & RB & DSLWW & DSRWW \\
\hline Type & - & $\mathbf{0}$ & $\mathbf{Y}$ & - & $\mathbf{1}$ & - & - & - \\
\hline Condition & $\mathbf{Y}$ & - & $\mathbf{1}$ & - & $\mathbf{2}$ & - & - & - \\
\hline Extent & $\mathbf{1}$ & - & $\mathbf{0}$ & $\mathbf{1}$ & $\mathbf{0}$ & $\mathbf{0}$ & $\mathbf{0}$ & - \\
\hline
\end{tabular}

Bank / Bridge protection types: 0- absent; 1- < 12 inches; 2- < 36 inches; 3- < 48 inches; 4- < 60 inches; 
83. Wingwall and protection comments (eg. undermined penetration, unusual scour processes, etc.):

-
-
-
-
-
5
1
1
0
-
-

\section{Piers:}

84. Are there piers? 80. (Y or if $N$ type ctrl-n pr)

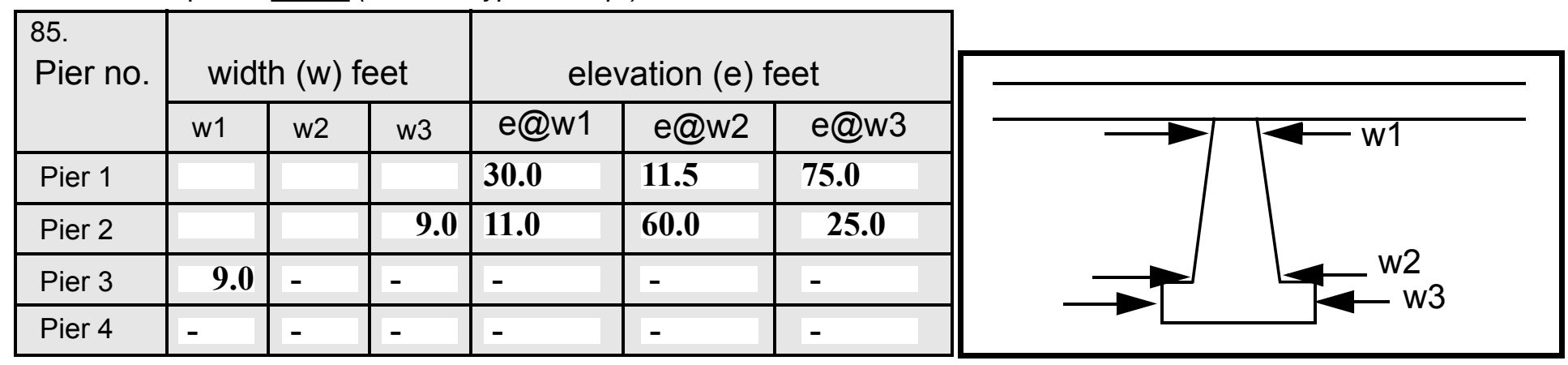

\begin{tabular}{|l|l|l|l|l|}
\hline Level 1 Pier Descr. & \multicolumn{1}{|c|}{1} & \multicolumn{1}{|c|}{2} & \multicolumn{1}{|c|}{3} & \multicolumn{1}{|c|}{} \\
\hline 86. Location (BF) & The & DS end & tec- & couple \\
\hline 87. Type & US & of & tion & of \\
\hline 88. Material & left & the & is & large \\
\hline 89. Shape & wing & wing & type- & stone \\
\hline 90. Inclined? & wall & wall. & 1 at & s, \\
\hline 91. Attack $\angle$ (BF) & foot- & $\mathbf{8 2 .}$ & the & type- \\
\hline 92. Pushed & ing is & The & US & 2 \\
\hline 93. Length (feet) & - & - & - & - \\
\hline 94. \# of piles & expo & US & end. & pro- \\
\hline 95. Cross-members & sed & left & Ther & tec- \\
\hline 96. Scour Condition & for 5 & wing & e are & tion, \\
\hline 97. Scour depth & ft at & wall & also & alon \\
\hline 98. Exposure depth & the & pro- & a & g the \\
\hline
\end{tabular}

LFP, LTB, LB, MCL, MCM, MCR, RB, RTB, RFP

1- Solid pier, 2- column, 3- bent

1-Wood; 2- concrete; 3- metal; 4- stone

1- Round; 2- Square; 3- Pointed

Y-yes; $N$ - no

$L B$ or $R B$

0- none; 1- laterals; 2- diagonals; 3- both

0- not evident; 1- evident (comment);

2- footing exposed; 3- piling exposed;

4- undermined footing; 5- settled; 6-failed 
99. Pier comments (eg. undermined penetration, protection and protection extent, unusual scour processes, etc.):

entire base length, but they are out in the channel rather than close to the wingwall. At the DS left wingwall there is a second wall between the concrete wingwall and the channel. This wall is large stone slabs laid-up in line with left abutment but set back about 9 in.

$\mathbf{N}$

100.

\section{E. Downstream Channel Assessment}

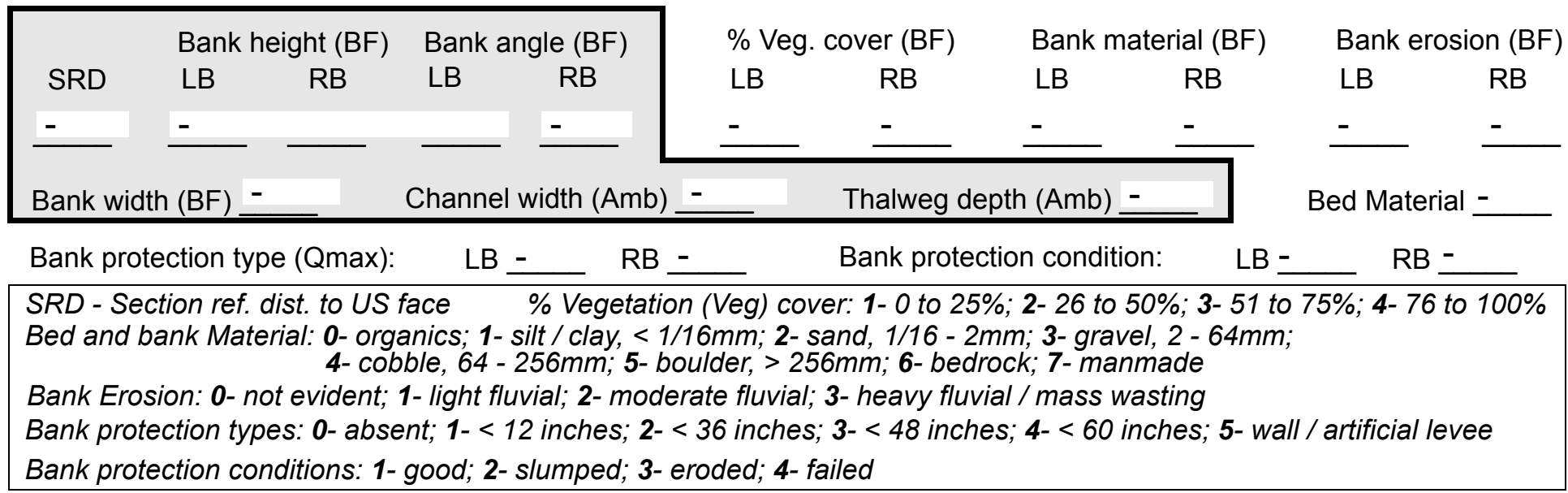

Comments (eg. bank material variation, minor inflows, protection extent, etc.):

$-$

$-$

$-$

$-$

$-$

$-$

$-$

$-$

$-$

$-$

$-$

$-$

101. Is a drop structure present? _ ( $Y$ or $N$, if $N$ type ctrl-n ds) 102. Distance: ___ feet
103. Drop: - feet
104. Structure material:
(1- steel sheet pile; 2- wood pile; 3- concrete; 4- other)

105. Drop structure comments (eg. downstream scour depth): 
106. Point/Side bar present? (Y or $N$. if $N$ type ctrl-n pb)Mid-bar distance:

Mid-bar width: -

Point bar extent: feet -

(US, UB, DS) to feet (US, UB, DS) positioned $\%$ LB to $\% \mathrm{RB}$ Material:

Point or side bar comments (Circle Point or Side; note additional bars, material variation, status, etc.):

S a cut-bank present? $\mathbf{N}$ (Y or if $N$ type ctrl-n cb) Where? $\underline{\mathbf{O}}$ (LB or RB) Mid-bank distance: PIE Cut bank extent: $\underline{\mathbf{R S}}$ feet ___ (US, UB, DS) to feet (US, UB, DS)

Bank damage: (1- eroded and/or creep; 2- slip failure; 3- block failure)

Cut bank comments (eg. additional cut banks, protection condition, etc.):

Is channel scour present? Scour dimensions: Length $\underline{2}$ Width 32 ( $Y$ or if $N$ type ctrl-n cs) Depth: 23 Mid-scour distance: 4 Scour comments (eg. additional scour areas, local scouring process, etc.): 453

1 2

2

Are there major confluences? 1 ( $Y$ or if $N$ type ctrl-n $m c)$ Confluence 1: Distance the Confluence 2: Distance $\mathbf{k}$, Enters on left ( $L B$ or RB) Enters on ther ( $L B$ or $R B$ ) Positioned 1 \%LB to 2 $\% \mathrm{RB}$ Confluence comments (eg. confluence name):

a gap in the tree cover from $40 \mathrm{ft}$ to $100 \mathrm{ft}$ DS. On the right bank, the vegetation cover is mainly shrubs to 45 ft DS, then further DS the tree cover becomes nearly $100 \%$.

\section{F. Geomorphic Channel Assessment}

107. Stage of reach evolution
1- Constructed

2- Stable

3- Aggraded

4- Degraded

5- Laterally unstable

6- Vertically and laterally unstable 
108. Evolution comments (Channel evolution not considering bridge effects; See HEC-20, Figure 1 for geomorphic descriptors):

e left bank protection protects the house and lawn. It is composed of a variety of protection materials, such as stones, bricks, old asphalt, and cut stone blocks. This protection extends beyond $200 \mathrm{ft}$ DS.

The right bank protection is just a few cut stones from the end of the wingwall to $30 \mathrm{ft}$ DS.

Between $52 \mathrm{ft}$ and $100 \mathrm{ft}$ DS there is a pooled area that is $1.25 \mathrm{ft}$ deep caused by randomly placed stones across the channel at each end. 


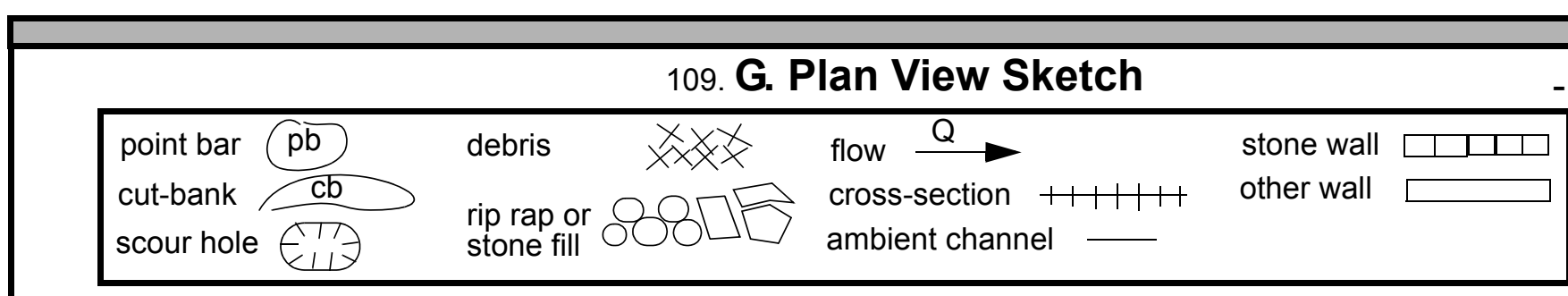


APPENDIX F:

SCOUR COMPUTATIONS 


\begin{tabular}{|c|c|c|c|}
\hline Structure Number: NFIETHOOPL0081 & & Town: & NORTHFIELD \\
\hline Road Number: $\quad$ PLEASANT ST. & & County: & WASHINGTON \\
\hline Stream: UNION BROOK & & & \\
\hline Initials RLB & Checked: & $\mathrm{EB}$ & \\
\hline Analysis of contraction scour, live & -bed or $\mathrm{cl}$ & lear wate & \\
\hline Critical Velocity of Bed Material & converted & to Engli & h units) \\
\hline (Richardson and others, 1995, p. 28 & eq. 16) & & \\
\hline Approach Section & & & \\
\hline Characteristic & $100 \mathrm{yr}$ & $500 \mathrm{yr}$ & other $Q$ \\
\hline Total discharge, cfs & 1590 & 2460 & 930 \\
\hline Main Channel Area, ft2 & 232 & 267 & 164 \\
\hline Left overbank area, ft2 & 102 & 156 & 0 \\
\hline Right overbank area, ft2 & 39 & 82 & 0 \\
\hline Top width main channel, ft & 43 & 43 & 42 \\
\hline Top width L overbank, ft & 67 & 67 & 0 \\
\hline Top width $\mathrm{R}$ overbank, ft & 46 & 59 & 0 \\
\hline D50 of channel, ft & 0.1566 & 0.1566 & 0.1566 \\
\hline D50 left overbank, ft & -- & -- & -- \\
\hline D50 right overbank, ft & -- & -- & -- \\
\hline Y1, average depth, $M C$, ft & 5.4 & 6.2 & 3.9 \\
\hline Y1, average depth, LOB, ft & 1.5 & 2.3 & ERR \\
\hline $\mathrm{y}_{1}$, average depth, ROB, ft & 0.8 & 1.4 & ERR \\
\hline Total conveyance, approach & 23541 & 35955 & 9722 \\
\hline Conveyance, main channel & 17068 & 21538 & 9722 \\
\hline Conveyance, LOB & 4979 & 10078 & 0 \\
\hline Conveyance, ROB & 1494 & 4340 & 0 \\
\hline Percent discrepancy, conveyance & 0.0000 & -0.0028 & 0.0000 \\
\hline Qm, discharge, MC, cfs & 1152.8 & 1473.6 & 930.0 \\
\hline Q1, discharge, LOB, cfs & 336.3 & 689.5 & 0.0 \\
\hline Qr, discharge, ROB, cfs & 100.9 & 296.9 & 0.0 \\
\hline $\mathrm{Vm}$, mean velocity $\mathrm{MC}$, ft/s & 5.0 & 5.5 & 5.7 \\
\hline Vl, mean velocity, LOB, ft/s & 3.3 & 4.4 & ERR \\
\hline Vr, mean velocity, ROB, ft/s & 2.6 & 3.6 & $\mathrm{ERR}$ \\
\hline Vc-m, crit. velocity, MC, ft/s & 8.0 & 8.2 & 7.6 \\
\hline Vc-1, crit. velocity, LOB, ft/s & ERR & ERR & ERR \\
\hline Vc-r, crit. velocity, ROB, ft/s & ERR & ERR & ERR \\
\hline Results & & & \\
\hline Live-bed(1) or Clear-Water(0) Contr & action $\mathrm{ScC}$ & our? & \\
\hline Main Channel & 0 & 0 & 0 \\
\hline Left Overbank & $\mathrm{N} / \mathrm{A}$ & $\mathrm{N} / \mathrm{A}$ & $\mathrm{N} / \mathrm{A}$ \\
\hline Right Overbank & $\mathrm{N} / \mathrm{A}$ & $\mathrm{N} / \mathrm{A}$ & $\mathrm{N} / \mathrm{A}$ \\
\hline
\end{tabular}


Clear water Contraction Scour in MAIN CHANNEL

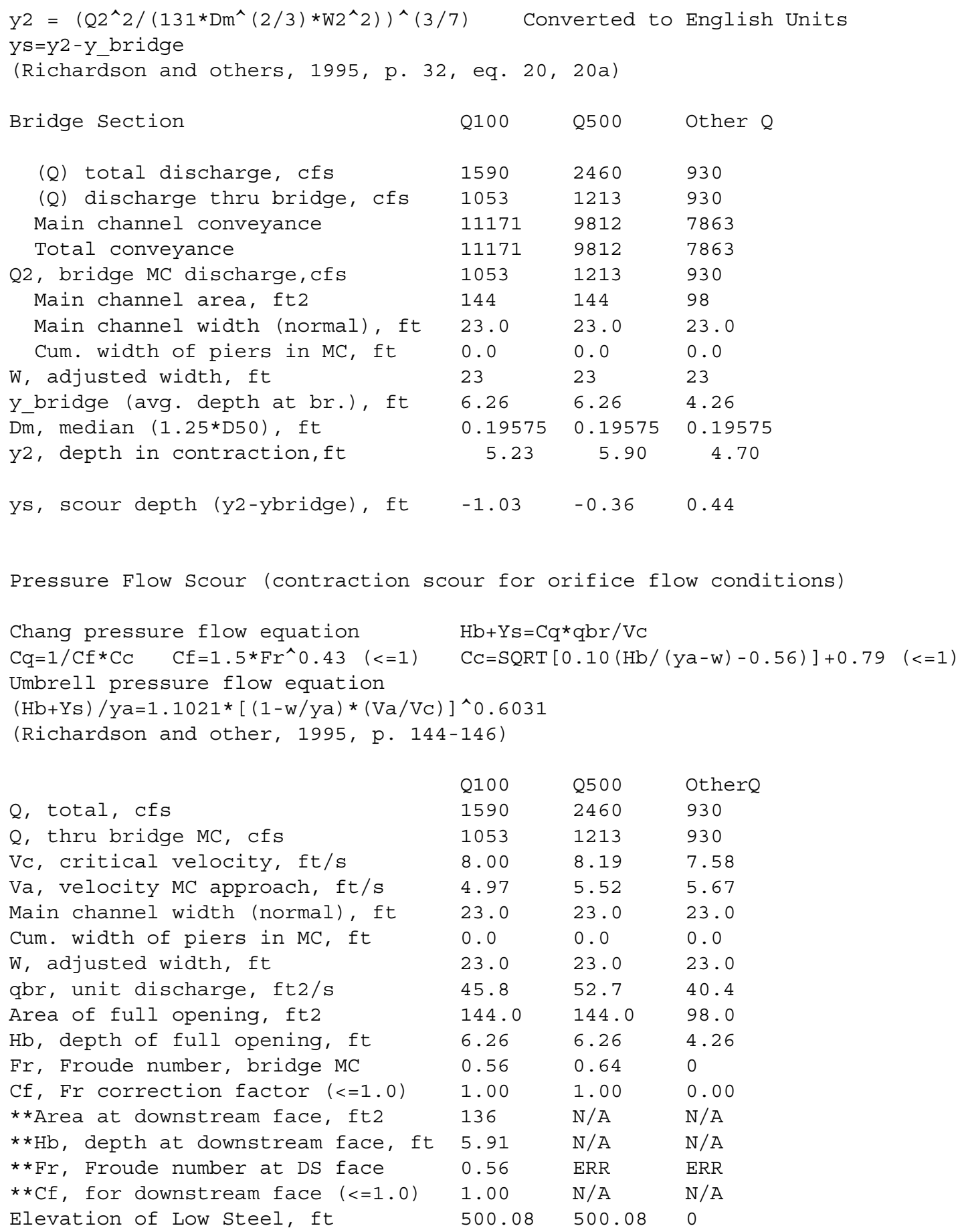




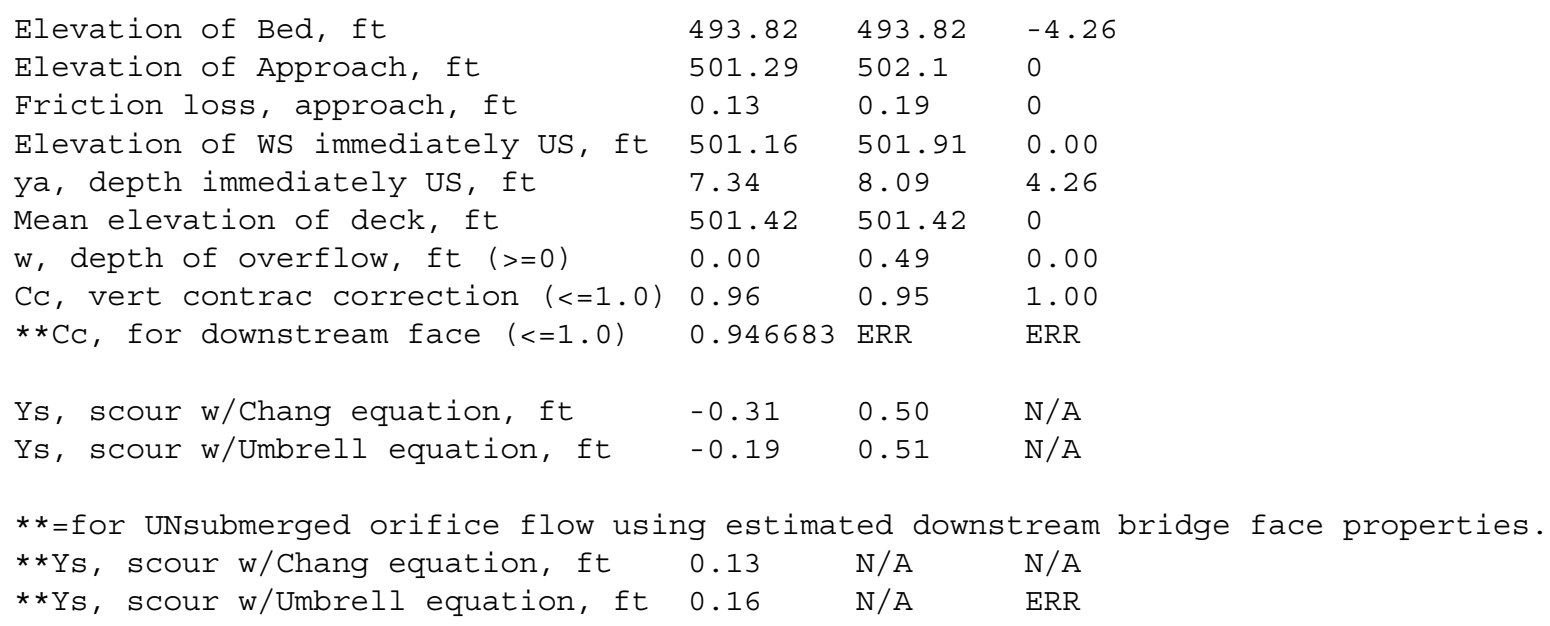

In UNsubmerged orifice flow, an adjusted scour depth using the Laursen equation results and the estimated downstream bridge face properties can also be computed (ys=y2-ybridgeDS)

$\begin{array}{llll}\text { Y2, from Laursen's equation, ft } & 5.23 & 5.90 & 4.70 \\ \text { WSEL at downstream face, ft } & 499.73 & -- & -- \\ \text { Depth at downstream face, ft } & 5.91 & \text { N/A } & \text { N/A } \\ \text { depth of scour (Laursen), ft } & -0.68 & \text { N/A } & \text { N/A }\end{array}$

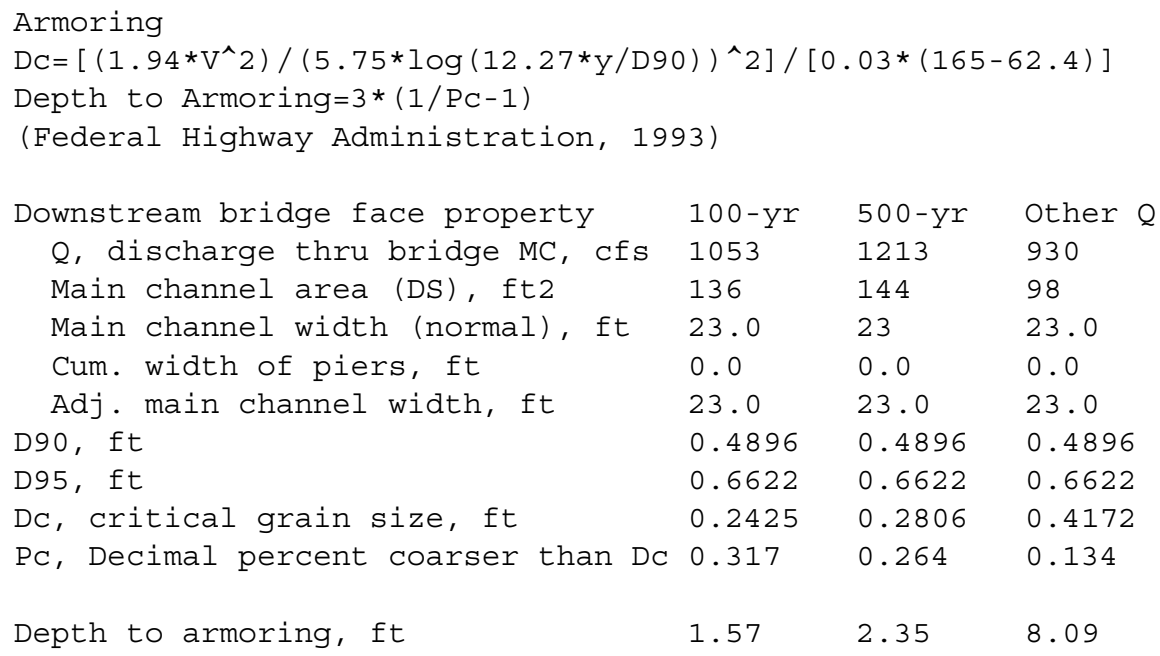

Abutment Scour

Froehlich's Abutment Scour

$\mathrm{Ys} / \mathrm{Y} 1=2.27 * \mathrm{~K} 1 * \mathrm{~K} 2 *\left(\mathrm{a}^{\prime} / \mathrm{Y} 1\right) \wedge 0.43 * \mathrm{Fr} 1 \wedge 0.61+1$

(Richardson and others, 1995, p. 48, eq. 28)

Characteristic

(Qt), total discharge, cfs

a', abut.length blocking flow, ft

Ae, area of blocked flow ft2

Qe, discharge blocked abut., cfs
Left Abutment $100 \mathrm{yr} Q 500 \mathrm{yr} Q$ Other Q $100 \mathrm{yr}$ Q $500 \mathrm{yr} Q$ Other Q

Right Abutment

$\begin{array}{rrrrrl}1590 & 2460 & 930 & 1590 & 2460 & 930 \\ 28.8 & 28.8 & 1.8 & 33.2 & 33.2 & 17.2 \\ 43.9 & 42.1 & 3.9 & 90.1 & 95 & 54.7 \\ -- & -- & 13.3 & -- & -- & 268.1\end{array}$




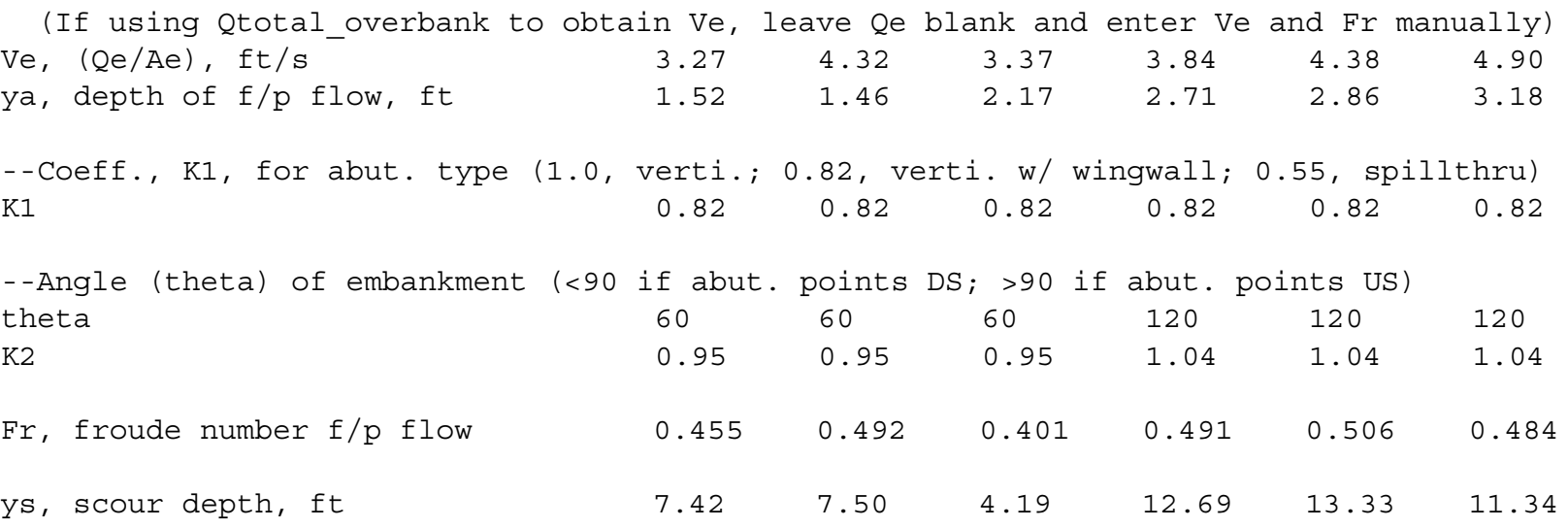

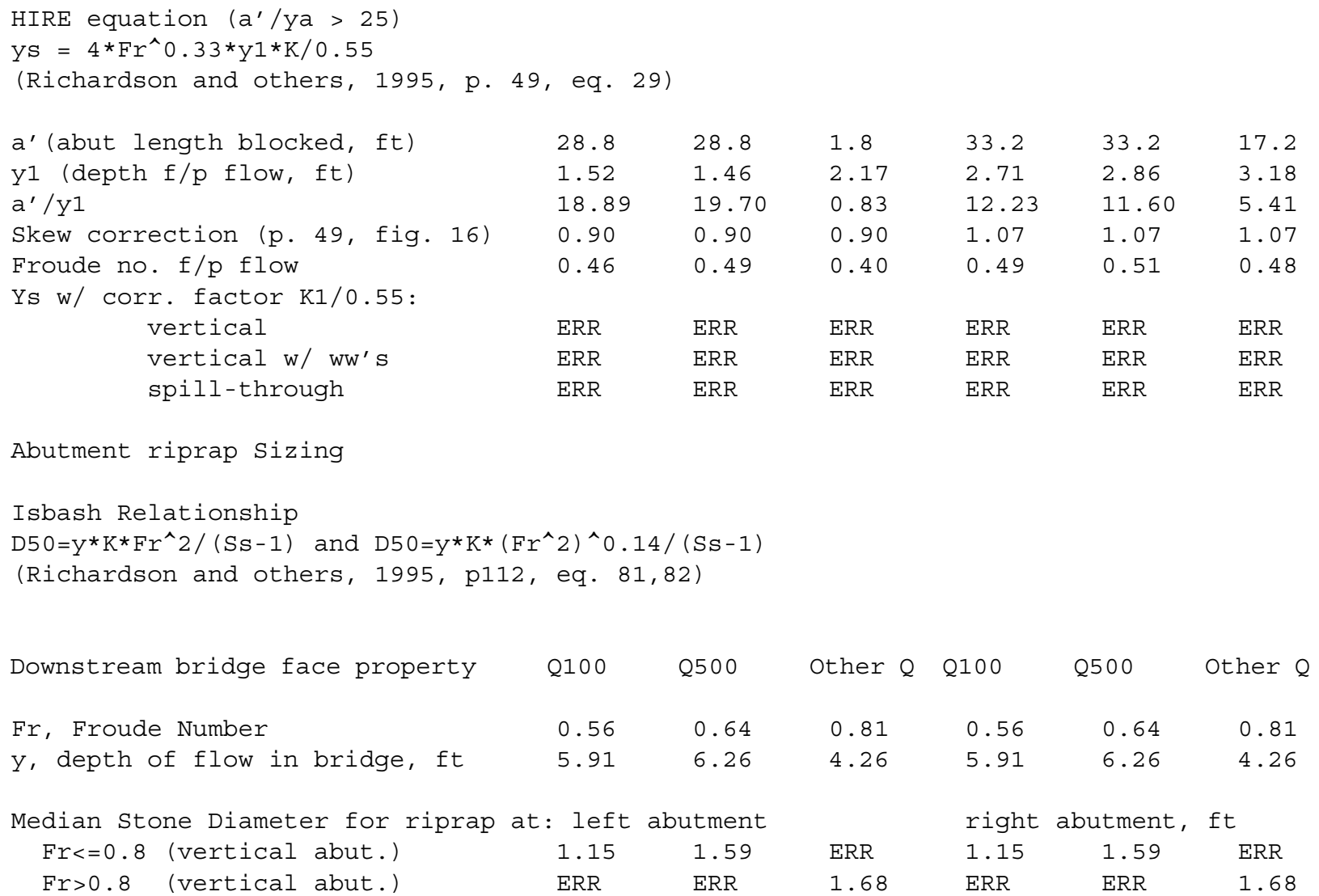


